第 Springer



PLANTS PEOPLE

POSSIBILITIES

\title{
Dioscorea sativa
}

\section{Author(s): D. Prain and I. H. Burkill}

Source: Bulletin of Miscellaneous Information (Royal Botanic Gardens, Kew), Vol. 1919, No. 9 (1919), pp. 339-375

Published by: Springer on behalf of Royal Botanic Gardens, Kew Stable URL: http://www.jstor.org/stable/4107717

Accessed: 27-06-2016 11:00 UTC

Your use of the JSTOR archive indicates your acceptance of the Terms \& Conditions of Use, available at

http://about.jstor.org/terms

JSTOR is a not-for-profit service that helps scholars, researchers, and students discover, use, and build upon a wide range of content in a trusted digital archive. We use information technology and tools to increase productivity and facilitate new forms of scholarship. For more information about JSTOR, please contact support@jstor.org.

Springer, Royal Botanic Gardens, Kew are collaborating with JSTOR to digitize, preserve and extend access to Bulletin of Miscellaneous Information (Royal Botanic Gardens, Kew) 
1914, also by Messrs. Sutton, who obtained it from MM. Vilmorin, Andrieux \& Co., of Paris.

Since the above was written there has appeared in the American Naturalist for March, 1919 (vol. liii.), a paper by Prof. Cockerell on the Varieties of Helianthus tuberosus, in which he enumerates and names six forms, all except the first having been grown by him in Boulder, Colorado.

These are: (a) typicus, the plant figured by Colonna, as to which Prof. Cockerell remarks "I have never seen a plant with exactly this combination of characters."

(b) nebrascensis, a wild form from Nebraska, also very floriferous, and with a pale brown skin.

(c) Alexandri, wild in Michigan; tubers white, with a very thin brownish skin.

(d) purpurellus, sent out by the firm of Childs as "Pink Helianthi," but without information as to its origin. Colour deep pinkish-purple, as in var. purpureus.

(e) fusiformis, the "Rose" variety of Messrs. Sutton.

(f) albus, of which the author says " We first got this, a number of years ago, from Dreer of Philadelphia. Mr. L. Sutton tells me that his firm first offered it in 1915, having obtained it from someone who said it had been sent him by a friend in South America. He believes it had not been grown in England before this. Dreer had it much earlier in this country, having obtained it from Mr. A. E. Coleman of Enonville, Va. Mr. Coleman states that he knows nothing of the origin of the variety."

It will be noticed that 1915 (possibly a misprint) is twenty-four years later than the true date of appearance of this variety in Sutton's lists. Unfortunately this mistake and the lack of a definite date for Mr. Coleman's acquaintance with albus, leave the relative priority of its introduction in England and in the U.S.A. undecided.

If Coleman had the plant earlier than 1889 it is probable that Pierce, who sold his stock to Suttons, must really have received the tubers from the United States.

(g) purpureus, received from Suttons as the variety long cultivated in England.

Of these forms (a) and (b) are much branched, floriferous forms; the rest are tall, less branched and more leafy, as they are known to us in cultivation. Other distinctive characters are pointed out in Prof. Cockerell's paper.

\section{XXV.-"DIOSCOREA SATIVA."}

\section{Prain and I. H. Burkill.}

Considerable difficulty has from time to time been experienced by systematic students in deciding what should be the precise incidence of the name Dioscorea sativa, first proposed by Linnaeus in $1753(S p . P l$. ed. 1 , p. 1033). The writers, in the course of a revision of the Asiatic species of the genus on which they have been engaged for a number of years, have had occasion to review the position adopted by previous students of the genus with the 
object of arriving at a definite conclusion. The nature of the conclusion to which they have been led is such as to render it desirable to explain how the difficulty experienced by their predecessors has arisen, and to give a brief historical review of the various attempts that have been made to solve it, as preliminaries to the statement of the results at which they have themselves arrived.

Though Linnaeus first applied specific names to components of the genus Dioscorea in 1753 he had already formed conceptions of the limitation of five out of the eight species then named as early as 1737 (Hort. Cliff. p. 459), and of two of the remaining three in 1747 (Flor. Zeyl. pp. 1r0-2). The terms in which these conceptions were expressed in 1753 are as follows; the dates of their respective formation are added in each case :-

pentaphylla. 1. Dioscorea foliis digitatis. Four references are given to assist in the interpretation of this conception; there is no specimen to illustrate it in the proper herbarium of Linnaeus: Hort. Cliff. (1737) n. 5.

triphylla. 2. Dioscorea foliis ternatis. Two references given; no specimen: Hort. Cliff. (1737) n. 4.

aculeata. 3. Dioscorea foliis cordatis, caule aculeato bulbifero. Four references; no specimen: Hort. Cliff. (1737) n. 3.

alata. 4. Dioscorea foliis cordatis, caule alato bulbifero. Five references; one specimen: Flor. Zeyl. (1747) n. 360.

bulbifera. 5. Dioscorea foliis cordatis, caule laevi bulbifera. Five references; one specimen: Hort. Cliff. (1737) n. 2.

sativa. 6. Dioscorea foliis cordatis alternis, caule laevi. Seven references; one specimen written up by Linnaeus, with another attached but not written up: Hort. Cliff. (17:3\%) n. 1 .

villosa. 7. Dioscorea foliis cordatis alternis oppositisque, caule laevi. Two references; no specimen: $S p$. Pl. (1753).

oppositifolia. 8. Dioscorea foliis oppositis ovatis acuminatis. 'Two references; no specimen: Flor. Zeyl. (1747) n. 361.

It may assist us in appreciating the situation if the diagnostic characters stated and implied by Linnaeus in this arrangement be presented in the form of a key, implied characters being placed within brackets.

Key to the Linnean species of Dioscorea.

Leaves digitate:-

[Leaflets more than three] 1. D. pentaphylla.

Leaflets three only 2. D. triphylla.

[Leaves simple] :-

Leaves cordate :-

Leaves with axillary bulbils :-

Stem armed with prickles

[Stem unarmed]:

Stem winged

Stem not winged

3. D. aculeata.

4. D. alata.

5. D. bulbifera. 


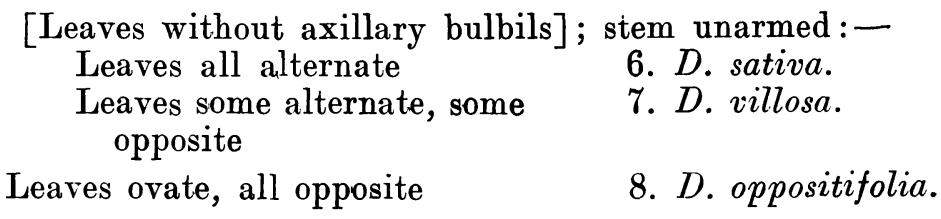

The main defect in this system, it will be seen, lies in the distinction relied upon in discriminating between $D$. sativa as delimited in 1737 and $D$. villosa, newly intercalated in the system in 1753, since specimens of the latter collected from such portions of the plant as may be unprovided with opposite leaves must of necessity be attributed to the former. Another defect, which in the existing state of botanical knowledge it was impossible to appreciate in 1753, results from the fact that species beset with prickles may produce shoots that, especially towards their extremities, are unarmed, and that species which produce bulbils in the same way may develop shoots, the leaves on which are not bulbilliferous, so that particular specimens derived from a plant that according to the above key are really referable to $D$. aculeata or to $D$. bulbifera may, in the absence of a knowledge of the whole individual to which they belonged, be placed of necessity under $D$. sativa. We shall find indications as we proceed that Linnaeus himself, and others who have relied, perhaps too implicitly, on his authority, have been led to interpret too widely the specific limits of D. sativa. On the other hand we shall find that those who have been led to realise the difficulty now explained have not always been in accord as to which of the incongruous elements that accord with the Linnean definition should enjoy the distinction of bearing the designation $D$. sativa.

It is not necessary for the purpose of our enquiry to deal exhaustively here with the various references and citations under the other seven segregates proposed by Linnaeus in 1753 . It is, however, desirable to understand exactly what the plants are which he treated as belonging to D. sativa. In 1737 (Hort. Cliff. p. 459) Linnaeus cited as the male of his species Ricophora indica s. Inhame malabarica, folio rotundo in acuminatissimum apicem mucronato (Pluk. Alm. p. 321) and Mukelengu (Rheed. Hort. Malab. vol viii. p. 9i. . 51). A reference to Plukenet shows that the descriptive phrase quoted was taken up by Plukenet from Hermann (Par. Bat. Prodr. p. 371) and a reference to Hermann shows that the phrase was coined by him to indicate the Mu-kelengu of Rheede. These two references to the male of D. sativa therefore both relate to the same Old World plant. Under the female of the same species Linnaeus cited three plants, all from the Western Hemisphere; 1. Dioscorea scandens, foliis tamni, tructu racemoso (Plum. Gen. p. 9); 2. Volubilis nigra, folio cordato nervoso (Sloan. Cat. Jam. p. 46 and Hist. Jam. vol. i. p. 140); 3. but in this case doubtfully, Rhizophora americana (Boerh. Ind. alt. Lugd.-Bat. vol. ii. n. 267). The plants of Plumier and Sloane were West Indian species, one known to us from Plumier's figures (Plum. Gen. t. 26 and Burm. Pl. Amer. Plum. t. 117. fig. 1), the other from Sloane's original specimen still preserved in the herbarium at the British Museum; 
that of Boerhaave was an American species grown in the open in the Leiden garden. In addition to the foregoing, Linnaeus included in this group of forms a plant growing in the garden of Mr. G. Clifford at Hartekamp which he had kept under observation during two successive seasons, but which had not flowered when the description given in the Hortus Cliffortianus was written. Facing the text (Hort. Cliff. p. 459) is a figure drawn by Ehret (Hort. Cliff. t. 28) to which Linnaeus makes no reference. This figure purports to be a portrait of the plant described by Linnaeus as Dioscorea foliis cordatis alternis, caule laevi; as, however, a prickle is shown at the base of one petiole and a fruiting raceme is depicted as arising from the axil of that particular leaf, we know that some modification must have taken place in the original drawing of the plant which, we learn from Linnaeus himself, had an unarmed stem and had failed to produce flowers.

In 1740 Royen (Flor. Leyd. Prodr. p. 527) repeated the synonymy of the Hortus Cliffortianus, citing the text but not the figure of 1737; the reference to the Hortus Malabaricus is also omitted by Royen, though Plukenet's notice of the Malabar plant is given.

In 1747 Linnaeus again dealt with Dioscorea foliis cordatis alternis, caule laevi (Flor. Zeyl. p. 170. n. 358) repeating the references of 1737 , but omitting the expression of doubt used by himself in the Hortus Cliffortianus and by Royen in his Prodromus, ${ }^{*}$ regarding the identity of Rhizophora americana, Boerh., and adding to his earlier citations that of Rossakinda from Burmann (Thes. Zeyl. p. 207). This Rossakinda is itself, as we learn from Burmann, whose work was published in 1737, taken up from Hermann (Mus. Zeyl. p. 27); the specimen of Rasakinda, the name of which appeared in 1717, is still in Hermann's kerbarium at the British Museum and is the one written up, by Linnaeus himself, for the Flora Zeylanica (Flor. Zeyl. n. 358).

Like Roven in 1740 , Jinnaeus in 1747 cites his own text of 1737 (Hort. Cliff. p. 459) but does not refer to Ehret's figure (Hort. Cliff. t. 28). In 1753 (Sp. Pl. ed. 1. p. 1033), when the trivial name 'sativa' was first proposed, Linnaeus at last acknowledged Ehret's plate as a figure of $I$. sativa, citing under the diagnosis the references Hort. Cliff. p. 459. t. 28; Flor. Zeyl. n. 358; and Roy. Flor. Leyd. Prodr. p. 527. The further references are now, however, reduced to three, those from Plumier, Sloane and Rheede, which are given in the order named; the references to Plukenet, Boerhaave and Burmann are omitted. In 1754 (Amoen. Acad. vol. iv. p. 133) Linnaeus accepted responsibility for the reference to $D$. sativa of Olus sanguinis, Rumph (Herb. Amboyn. vol. v. p. 482. t. 180), and in 1757 J. Burmann published the figure of Plumier's Discorea scandens, foliis tamni, fructu racemoso (Pl. Amer. Plum. p. 107. t. 117.

* It is possible, however, that the omission of the ? in this instance may be an inadvertence; the text of n. 358 in the Flora Zeylanica contains several typographical errors which had escaped the notice of Linnaeus, e.g. Pluk. Alm. 32 in place of 321 ; tammi instead of tamni; lugd. i. p. 207 for ii. p. 267; Herm. zeyl. where Burm. zeyl. is intended. This being so, the ? may have been overlooked, or may have been 'dropped' by the printer. 
fig. 1), omitting the analytical details which had already been published by Plumier himself in 1703 (Gen. t. 26). We find accordingly, in 1759 , the addition by Linnaeus of these two citations to his diagnosis of D. sativa (Syst. ed. 10. vol. ii. p. 1294). In 1763 ( $S p$. Pl. ed. 2. p. 1463) Linnaeus took up from Burmann's text of 1757 another reference, that by $P$. Browne (Hist. Jam. p. 360) to Plumier's West Indian plant. In 1767 (Syst. ed. 12. vol. ii. p. 656) and in 1770 (Syst. ed. 13. vol. iii. p. 656) Linnaeus amplified his diagnosis by adding the word tereti, in both instances repeating the citation of Rumph, but omitting the reference to Burmann's edition of Plumier. We may add here that in 1768 Burmann (Flor. Ind. p. 315)*, dealt with D. sativa exactly as it was dealt with by Linnaeus in the Species Plantarum, ed. 2. p. 1462.

Summarising the various elements included by Linnaeus under I). sativa we find:

1 , an American Dioscorea described by Linnaeus in 1737 (Hort. Cliff. p. 459) the contemporary figure by Ehret assigned to which (Hort. Cliff. t. 28) was not accepted as valid by Linnaeus till

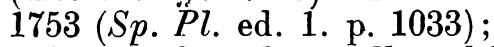

2, a Ceylon plant collected by Hermann and published by him in 1717 as Rasakinda, republished by Burmann in 1737 as Rossa. kinda and finally written up by Linnaeus himself in 1747 (Flor. zeyl. n. 358) as Dioscorea foliis cordatis alternis, caule laevi;

3, a Malabar Dioscorea figured by Rheede as Mu-kelengu (Hort. Malab. vol. viii. p. 97. t. 51);

4, a West Indian I)ioscorea, a figure of which by Plumier was published partly in 1703 (Plum. Gen. p. 9. t. 26), partly in 1755 (Burm. Pl. Amer. Plum. p. 107. t. 117. fig. 1), referred to by P. Browne in 1756 (Hist. Jam. p. 360) as the 'Wild Yam';

5 , another West Indian Dioscorea cited from Sloane (Cat. Jam. p. 46 and Hist. Jam. vol. i. p. 140) as Volubilis nigra, folio cordata nervoso;

6, an Amboyna plant figured by Rumph as Olus sanguini: (Herb. Amboyn. vol. v. p. 481. t. 180).

These for the sake of brevity will be referred to below as $D$. sativa, Linn. [1], [2], [3], [4], [5], [6].

In addition to the six entities enumerated above, the specimens which represent $D$. sativa in the proper herbarium of Linnaeus have to be taken into account. There is only one specimen which has been written up as $D$. sativa by Linnaeus himself; this specimen he obtained from Kalm. The second specimen, pinned to the foregoing but not written up by Linnaeus, is an example of a West Indian and South American Dioscorea, frequently accepted as belonging to $D$. polygonoides, Humb. and Bonpl.,, and nearly allied to but easily distinguished from $D$. sativa, Iinn. [4], the West Indian Dioscorea figured by Plumier. It differs from any of the elements of $D$. sativa, Linn., and may therefore be

* This is a printer's error for p. 215-the sheet of which the page forms part having been mispaged throughout.

+ There is an element of doubt as to the precise identity of this plant owing to the circumstance that the name $D$. polygonoides is applied in herbaria to more than one species; we have so far failed to obtain access to an authentically named example of Humboldt and Bonpland's original plant. 
neglected. The specimen which Linnaeus has written up as $D$. sativa with his own hand is a male example of the North American species named by himself $D$. villosa ( $S p . P l$. ed. 1 . p. 1033. n. 7). It differs from the Amboyna, the Malabar, the Ceylon, and both of the West Indian constituents of D. sativa, Linn.; it agrees as regards its foliage with the plant figured by Ehret (Hort. Cliff. t. 28) which professes to be D. sativa, Linn. [1], and there is nothing in its appearance or characters to separate it from the plant described by Linnaeus in the Hortus Cliffortianus in 1737 as $I$. foliis cordatis alternis, caule laevi.

In 1768 the name $D$. sativa, Linn., was used by Miller (Gard. Dict. ed. 8. No. 1) for a West Indian plant, seeds of which had been sent to England by Houston before 1733. In the field Houston had identified this with Dioscorea scandens, foliis tamni, fructu racemoso. The notes of Houston and the description supplied by Miller indicate that the plant intended is that figured by Plumier. D. sativa, Mill., is therefore certainly $=D$. sativa, Linn. [4], so far as Miller's description is concerned. But in Miller's Herbarium as in that of Linnaeus there are two specimens of D. sativa; in this case both have been written up by Miller himself. One of the two, evidently taken from a plant grown in the open is, as in the case of the Linnean collection, $D$. villosa, Linn.; the other, equally clearly derived from a stoveplant, is D. sativa, Linn. [4], the species whose seeds, Miller explains (Gard. Dict. l.c.), had reached him through Houston from Jamaica. In the Cambridge herbarium there is another specimen of the same stove-plant, given by Miller to Martyn.

In 1784 the name D. sativa, Linn., was used by Thunberg (Flor. Japon. p. 151) for a cultivated Japanese Yam, termed 'kasjuo kadsura.' This plant differs from all the elements included by Linnaeus under $D$. sativa and belongs instead to one of the two species included by Linnaeus under $D$. bulbifera, Linn. ( $S p$. Pl. ed. 1. p. 1033. n. 5). In Thunberg's own proper Herbarium, however, we find that he has also written up as $D$. sativa a specimen which is really referable to his own species $D$. japonica.

In 1788 the name D. sativa, Linn., was used by Gaertner (Fruct. p. 66) in such a manner as to include, so far as citations and references are concerned, all of the plants included by Linnaeus under D. sativa except D. sativa, Linn. [5], which is the West Indian Dioscorea taken up from Sloane. The description, however, is confined exclusively to the plant which is the subject of Gaertner's plate (Fruct. t. 17. fig. 4). That plate is a somewhat improved version of the one used by Plumier in 1703 (Gen. t. 26) to illustrate his D. scandens, foliis tamni, fructu racemoso, so that, strictly interpreted, D. sativa, Gaertn. (1788) is =D. sativa, Mill., as described in 1768, and = D. sativa, Linn. [4].

In 1789 the incidence of the name $D$. sativa, Linn. was critically discussed by Lamarck (Encyc. Meth. vol. iii. p. 232). He arrived at three definite conclusions:--

1, that Ehret's figure, published in 1737 and acknowledged for the first time by Linnaeus in 1753, must be regarded as the real basis of the name $D$. sativa, Linn.;

2 , that the plant represented in Ehret's figure differs specifically from all the other elements included by Linnaeus under 
D. sativa: Lamarck made no attempt to identify any one of these incongruous elements but he did particularly advert to the circumstance that the species with broad capsules figured by Plumier, which is D. sativa, Linn. [4], cannot possibly be conspecific with the plant figured by Ehret, which is $D$. sativa, Linn. [1];

3 , that the plant figured by Ehret, not being one of the cultivated Yams, ought not to be designated 'sativa': this name Lamarck consequently rejected altogether, substituting for it the name D. Cliffortiana, Lamk (Encyc. Meth. l.c.).

Even as regards the identity of the plant which he thus named D. Cliffortiana, Lamarck was doubtful, though it appeared to him possible that it might be the plant, then represented only by male examples, which throve in the open in the Royal Garden at Paris and was known there in 1789 as $D$. sativa. This plant, Lamarck states, had all the characters of the Dioscorea from Florida figured by Plukenet (Alm. p. 46. t. 375. fig. 5), which was cited by Linnaeus in 1753 under $D$. villosa, Linn. ( $S p . P l$. ed. 1. n. 7). We know now, what Lamarck probably did not know, that Miller may have held the same view, since one specimen written up by Miller as $D$. sativa, Linn., is $D$. villosa, Linn. We also know, what Lamarck certainly did not know, that Linnaeus himself was in like case, since the only specimen which he has written up as $D$. sativa-and he received that plant from Kalm prior to 1753 -is his own $D$. villosa. It is more convenient to digress for the moment from the chronological sequence of our references and explain the fate which befel Lamarck's conclusions. Lamarck thought it desirable to prepare a plate to illustrate the genus Dioscorea, thus repeating a step which Plumier had already taken in 1703 (Gen. t. 26). The date of issue of Lamarck's plate is not quite clear, but is believed to have been about 1798 . The plate itself shows (Lamk. Ill. t. 818) that he preferred to employ for the purpose figures already familiar to botanists rather than to provide drawings made from specimens of species less generally known. As illustrating a male Disscorea he therefore employed an adaptation of one branch from Rheede's figure of Mu-kelengu (Hort. Malab. vol. vii. t. 51); as illustrating a female Dioscorea he was satisfied with a repetition of the version by Gaertner (Fruct. vol. i. t. 17. fig. 4) of the species chosen by Plumier (Gen. t. 26). Both of the species selected had been included by Linnaeus under $D$. sativa in 1753 ; they constitute $D$. sativa, Linn. [3] and D. sativa, Linn. [4], respectively Both of them had, however, been explicitly excluded from $D$. sativa, Linn., in 1789, by Lamarck himself. In conformity with the decision at which he had then arrived we find that Lamarck refrained from suggesting on his plate a specific name for either of the species figured. In any case he was under no necessity to make such a suggestion; his immediate purpose was to illustrate the genus as a whole. The text deemed necessary to elucidate Lamarck's plate was not published until 1823. For this text Poiret, who continued Lamarck's studies, was responsible. In this text (Tabl. encyc. Meth. vol. iii. p. 429) Poiret states that Lamarck's plate (Ill. t. 818) represents $D$. sativa, Linn. This statement is in one sense correct, since of the two species there figured one is $D$. 
sativa, Linn. [3], and the other is $D$. sativa, Linn. [4]; Poiret was quite entitled to accept, if he chose, the considered judgment of Willdenow, expressed in 1806, that the two plants concerned ought both to be included in D. sativa. But Poiret's preliminary statement, which is that this plate (Ill. $t$. 818) represents $D$. Cliffortiana, Lamk, is contrary to Lamarck's definite statement that $D$. Cliffortiana must be regarded as restricted to the species which forms 1 . sativa, Linn. [1], and is in opposition to Lamarck's explicit intimation that the two species there depicted, which are $D$. sativa, Linn. [3] and $D$. sativa, Linn. [4], should be excluded. Poiret's action, the responsibility for which has at times been attributed to Lamarck himself (conf. Flor. Brit. Ind. vol. vi. p. 296), is so unwarranted that it can only be explained as the result of inadvertence.

In 1796 the name D. sativa was applied by Rodschied (Bemerk. Essequeb. p. 57) to a Dioscorea found by him in Dutch Guiana. His specimens, from the words of Arowabisch, in which the plant is wild, were studied by G. W. F. Meyer in 1818, and were found to represent a species different from any of the elements included by Linnaeus under $D$. sativa. This species was describer as D. lutea, Meyer (Prim. Fl.Esseq. p.282), and whem characterising it Mever took occasion to endorse the view expressed by Lamarck in 1789, insisting in particular that the Amboyna plant of Rumphius, which is $D$. sativa, Linn. [6], must be excluded from the species intended by Linnaeus.

In 1806, Willdenow in re-editing the Species Plantarum nade very little modification in the conception of $D$. sativa enunciated by Linnaeus. The West Indian species taken up from Sloane, J. sativa, Linn. [57, which Gaertuer had not cited in 1788, was again included and the only Jinnean element left out is the other West Indian species taken up from Plumier, 1). sativa, Linn. [4]. With regard to this particular plant the argument advanced by Lamarck in 1789 could not be disregarded; it was accordingly transferred by Willdenow (Sp. Pl. ed. Willd. vol. iv. p. 795) to $D$. piperifolia, Humb \& Bonpl.* There are, however, indications that Willdenow must have felt the difficulty with regard to the identity of $D$. sativa that had been experienced by Lamarck, by Miller and by Linnaeus himself. The sheet in Willdenow's own herbarium which has been written up as $D$. sativa is stated both by Grisebach (Mart. Flor. Bras. vol. iii. p. 43) and by Kunth (Enum. vol. v. p. 340) to bear the number 18422. According to Grisebach the specimen so numbered is the East Indian D. deltoidea, Wall. (Cat. Lith. n. 5110); according to Kunth this specimen is a male example, collected by Hunnemann, of that form of the North American D. villosa, Linn., which was described by Walter in 1788 as D. quaternata (Flor. Carol. p. 246). Unless there be two sheets in Willdenow's

* This involved the introduction of a new confusion owing to the circumstance, of which Willdenow does not appear to have been aware, that Plumier's plant, D. sativa, Linn. [4]. twines to the left, has only three fertile stamens, and has seeds which are winged all round, whereas $D$. piperifolia, Humb. and Bonpl., twines to the right, has six fertile stamens and has seeds which are winged only at the top. In $1800^{\circ}$, however, the taxonomic value of these morphological differences were not so fully appreciated as they are now. 
herbarium, both bearing the number 18422, the two statements cannot be reconciled, though their joint testimony makes it clear that $D$. sativa, as understood by Willdenow, excluded D. sativa, Linn. [2], [3], [5], and [6] as well as D. sativa, Linn. [4]. Even the explicit exclusion by Willdenow of $D$. sativa, Linn. [4], appears to have produced little benefit if we may judge from the action of Aiton in 1813. Aiton's D. sativa (Hort. Kew. ed. 2. vol. v. p. 392), though by citation identical with D. sativa, Willd., is in reality the West Indian species, introduced by Houston, which was described as $D$. sativa by Miller in 1768. Now Houston's plant is the species figured by Plumier which constitutes $D$. sativa, Linn. [4], the solitary component of the Linnean species that Willdenow has been at pains to transfer to D. piperifolia, Humb. \& Bonpl. Therefore D. sativa, Ait., and D. sativa, Willd., so far from being identical, are mutually exclusive. The citation by Aiton of Rheede's $M u$ Kelengu, in place of mitigating, only accentuates this criticism, for Aiton claims that his D. sativa is a native of the West Indies whereas Rheede's plant is an Asiatic species.* The same confusion was perpetuated by Sweet (Hort. Suburb. p. 216) in 1818. Sweet's $D$. aculeata, introduced from India in 1803 and thought by him to be Rheede's Kátu-Keléngú (Hort. Malab. vol. vii. t. 37) was almost certainly the Mu-keléngú. His $D$. sativa on the other hand, which was introduced from the West Indies in 1733, though Sweet imagined it to be Rheede's Mu-kelengu (Hort. Malab. vol. viii. t. 51) was clearly the Houston-Miller plant.

In 1827 Blume used the name D. sativa (Enum. Pl. Jav. p. 23) for two plants from Java which he regarded as varieties of one species and considered to be conspecific with the Mu-kelengu of Rheede from Malabar. He cites in addition D. sativa, Willd., as defined in 1806 , so that nominally his $D$. sativa should include the Linnean elements [1], [2], [3]. [5], and [6]. He also cites Sprengel's reference of 1825 (Syst. vol. ii. p. 152) which is too general to be a guide. The description of $D$. sativa which Blume furnishes is incomplete; it gives no account of the tubers or of the floral structure. The account of the disposition, shape and especially the secondary venation of the leaves, renders it clear, however, that the plant before Blume must either have been the $M u$-kelengu of Rheede, which he evidently believed it to be, or have been that species included by Linnaeus under $D$. bulbifera in 1753 which we have to regard as D. bulbifera, Linn. [1]. The statement that the leaves of the Java species are glabrous renders its identity with $M u$-kelengu doubtful, since in Mu-kelengu the leaves are almost always more or less pubescent; the statement that the stem is unarmed strengthens this doubt, since it is rare for $M u$-kelengu to be without prickles at least at the base of the petiole. Finally the statement that in the male of the Java species the spikes are fascicled and that in the female the spikes

* We make this remark nothwithstanding the circumstance that one species from Central America, D. cymulosa, Hemsl. (Biol. Centr. Amer. vol. iii. p. 355), was identified in $1892 \mathrm{with}$ the $M u$-Kelengu of Rheede. The particular plant with which $D$. cymulosa was then associated (Flor. Brit. Ind. vol. v. p. 291) is one from Burma (Wall. Cat. n. $5103 \mathrm{C}, \mathrm{F}$ ) which in the first place is not the Mu-Kelengu (Wall. Cut. n. $5103 \mathrm{~A}, \mathrm{D}, \mathrm{E}$ ) and further is not D. cymulosa. 
are simple but crowded, renders the identification with $M u$-kelengu impossible; in Rheede's plant the spikes in both sexes are always solitary. When we turn to the only other known Java species with transverse veins such as Blume attributes to the leaves of his plant, the difficulty disappears, for in that plant, which is $D$. bulbifera, Linn. [1], the leaves are always glabrous, the stem is unarmed, and it is moreover the only Java species in which we find a 'cluster' of simple female axillary spikes. The greatest difficulties connected with Blume's account of $D$. sativa are his statement that the male spikes are not only fascicled but paniculate, and the fact that he has described $D$. bulbifera as a species apart. So far as the latter difficulty is concerned it has, however, to be borne in mind that Roxburgh, an equally competent observer, felt justified in describing as distinct species, $D$. pulchella and D. crispata, what we now know to be only marked and readily distinguishable forms of $D$. bulbifera, Linn. [1]. As regards the former difficulty it has to be remembered that towards the ends of the fiowering twigs of $D$. bulbifera the leaves in whose axils the fascicles of simple male-spikes arise, often are much reduced and sometimes are obsolete. When this occurs the postulated paniculate appearance is produced, and this condition is so frequent that Roxburgh, in his account of $D$. crispata (Flor. Ind. vol. iii. p. 802), describes the male flowers as panicled. Unfortunately there is no Dioscorea in the Leiden collection which has been written up by Blume himself as $D$. sativa. This defect is, however, remedied by the fact that in the Buitenzorg herbarium there is a specimen "ex herb. Blume" which is $D$. bulbifera, Linn., but which has been written up as $D$. sativa. It appears therefore as nearly certain as may be that the plant which Blume believed to be identical with the Dioscorea figured by Rheede as the $M u$-kelengu was in reality $D$. bulbifera, Linn. [1], and that whatever his intention may have been Blume, without being cognisant of the fact, in 1827 used the name D. sativa as Thunberg had used it in 1784 .

In connection with this question of $D$. sativa as understood by Blume, we may remark that in 18:39 Dillwyn (Rev. Ref. Hort. Malab. p. 40) regarded $M u$-kelengu as being D. sativa, Linn., and that in 1844 Hasskarl (Cat. alt. Hort. Bogor. p. 34) followed Blume so far at least as 'form' is concerned, though we have no means of judging whether D. sativa, Hassk. (1844), and D. sativa, Bl. (1827), be really the same plant. We do, however, know from its diagnosis that $D$. sativa, var. $\beta$, Hassk. was not the same plant as $D$. sativa, var. $\beta, \mathrm{Bl}$.; from Hasskarl's indication it is obvious that his $D$. sativa, var. $\beta$, really was one of the forms of the Mu-lielengu of Rheede. We know, too, that in 1867 Hasskarl (Hort. Malab. Clav. p. 67) restricted the name $D$. sativa to Mu-kelengu.

In 1827 Presl applied the name $D$. sativa (Rel. Haenk. fasc. 2, p. 134) to a Dioscorea collected by Haenke in the mountains of Huanaco in Peru. From Presl's citations we find that he now definitely excluded from $D$. sativa, Linn., the Amboyna plant of Rumph, D. sativa, Linn. [6]. In thus following the advice given by Meyer in 1818, Presl went a step further and expressed the opinion that Rumph's plant is not a Dioscorea at all. 
Presl also, at least in intention, excluded the West Indian species of Plumier, D. sativa, Linn. [4]; following Willdenow, he referred this to D. piperifolia, Humb. and Bonpl. But his action in this respect was imperfect; he cited Gaertner's figure and description under $D$. sativa Linn., without observing that the plant of Gaertner is also that of Plumier, so that according to Presl, D. sativa, Linn. [4], finds a place under two different species. What the actual species which Haenke collected and Presl described as $D$. sativa may be, is not clear; it certainly is no part of $D$. sativa, Linn., since none of the elements of that aggregate occur in Peru. It does not appear even to be identical with D. sativa, Rodsch. non linn. (1796); at all events no Peruvian specimens of that species, which is D. lutea, Meyer (1818), have so far been met with by us.

In 1830 Maycock (Flor. Barbad. p. 390) restricted the name D. sativa to a single West Indian cultivated Dioscorea, other than D. alata, Linn., and other than I?. bulbifera, Linn. Maycock excluded from 1). sativa, the 'Wild Yam' of Browne l.c., footnote), which Willdenow had included, and in effect confined the name $D$. sativa to the Volubilis nigra, radice tuberosa compressa, whose identity with 1). cayenensis, Lamk, is proved by Sloane's original specimen. But D. cayenensis sometimes is unarmed, at other times has the stem beset with prickles, and Maycock was led to regard these two states of this species as distinct. As a consequence he referred the armed condition of the species to $D$. aculeata, Linn., and thereby separated the Volubilis nigra, radice tuberosa compressa of Sloane from the Dioscorea foliis cordatis, caule tereti aculeato of Browne (l.c. p. 389, footnote). Maycock has, however, explained that he had no opportunity of informing himself how far the Yams actually cultivated in Barbados are distinct species or only varieties (l.c. p. 391, footnote), so that we do not know how far his judgment as to the difference between the plants of Sloane and Browne might have been modified by field-study. But Maycock at least shares with Blume the merit of having appreciated independently that, for the sake of convenience, if for no other reason, the name $D$. sativa should be applied to a cultivated Yam, and should, if possible, be restricted to only one Yam.

In 1831 Bunge used the name 1). sativa (Enum. Pl.Chin.p. 64) for a cultivated Chinese Yam which differs from the cultivated Japanese Yam taken for D. sativa by Thunberg in 1784, and also differs from all the plants included under $D$. sativa by Linnaeus. D. sativa, Bunge, is the cultivated Yam known in Japan as 'Tsukne-imo,' first named by Thunberg in 1784. Thunberg's name, D. opposita (Flor. Japon. p. 151), having been overlooked, this garden plant was described by Turczaninow in 1837 as $D$. polystachya (Bull. Imp. Soc. Nat. MLosc. vol. xi. n. 7. p. 158). This name was in turn overlooked and the species was redescribed by Decaisne in 1854 as D. Batatas (Rev. Hort. sèr. 4. vol. iii. p. 243). What is a distinct cultivated form of the same species, not however differing sufficiently from the type to be regarded even as a variety, was described by Carrière in 1865 as $D$. Decaisneara (Rev. Hort. 1865, p. 111).

In 1832 the name D. sativa, Herb. Madras, was employed by 
Wallich when distributing the herbarium collection of the East India Company (Wall. Cat. Lith. n. 5108). The specimen to which this name is given was collected by Rottler in Travancore in October, 1814; the field-note is inscribed:- " may be perhaps an autumnal state of $D$. oppositifolia, Iinn., though the description does not tally." Another note attached to the specimen, also in Rottler's handwriting, bears the words " an D. sativa?" With this plant Wallich associated in his distribution six other gatherings (n. 5108 B-G) that do not now concern us, because Wallich does not vouch for their absolute identity with Rottler's plant. Fortunately there is no doubt as to what Rottler's D. sativa is, because Hooker has made it the type of the male portion of D. Wallichii, Hook. f. (Flor. Brit. Ind. vol. vi. p. 295). Since 1892, when Hooker's description was published, the species has been collected again by Bourdillon in Travancore, where it is known as Katu-katsjil. This name is one used by Rheede (Hort. Malab. vol. vii. p. 69. ‘. 36) for a female Dioscorea included by Linnaeus ( $S p$. Pl. ed. 1. p. 1033) under D. bulbifera. We know that the Katu-katsjil is not D. bulbifera, Linn. [1], because the basis of the Linnean species is a plant with stems twining to the left, with reflexed capsules that are longer than broad, and with seeds that are winged at the top only, whereas Katu-katsjil has, as Rheede's figure shows, stems that twine to the right and capsules that point forward and are rather broader than they are long; its seeds, as Rheede's description implies, are winged all round. The only difference between the Katukatsjil as figured by Rheede, and $D$. Wallichii as described by Hooker, lies in the presence of axillary bulbils in Rheede's plant; so far we have found no trace of axillary bulbils in any of the numerous specimens of $D$. Wallichii examined by us. What is more often overlooked is that Rheede has figured and described as Kattu-kelengu (Hort. Malab. vol. vii. p. 71.t. 3r) the male of the species of which Katu-katsjil is the female, the only difference between the two, apart from the sexual one, being that in Kattukelengu the stem is sparingly prickly, in Katu-katsjil it is unarmed. This circumstance has induced Linnaeus to regard Kattu-kelengu as the basis, of his $D$. aculeata ( $S p$. Pl. ed. 1 . p. 1033). In D. Wallichii, Hook. f., which nowadays certainly bears the name Katu-katsjii, we find that prickles may be present or absent in either sex, and this character, notwithstanding the importance attached to it by Linnaeus, is in many other species of equallv slight significance. The character afforded by the presence of axillary bulbils, so clearly shown in both of Rheede's plates and so definitely insisted upon in Rheede's two descriptions, cannot, however, be disregarded. Nowhere in India have we been able to find a Dioscorea that agrees, as $D$. Wallichii does in every other respect, with the species figured by $\mathrm{Rheede}$ (1.c. tt. 36, 37) and at the same time produces axillary bulbils. If this character supplied by Rheede be strictly accurate, D. aculeata, Linn. [1] and $D$. Wallichii, Hook. f., must be accepted as specifically distinct. The adoption of this conclusion would, however, involve the acceptance of the hrpothesis that since 1688 the incidence of the vernacular name Katu-katsjil has been altered. Students acquainted only with western peoples can point to 
incidents of the kind; the name "potato' which in England, when Shakespeare wrote, connoted Ipomoea Batatas and no other plant, is now among us exclusively restricted to Solanum tuberosum; the name ' pomme de terre,' now confined in France to this Solanum, was at the opening of the eighteenth century as rigidly restricted to Helianthus tuberosus. Those, however, whose experience has extended to Eastern races cannot fail to regard as singularly unlikely an assumption that there has been a change in the incidence of the name Katu-katsjil. Nor is such a hypothesis necessary. Regarding Katu-katsjil Rheede says:"species est T'sjagari-Nuren, respectu radicis fructuum et verrucarum." No figure of the underground tuber is given in the case of either plant so that respectu radicis criticism is precluded. But when we examine the figure of Tjageri-Nuren* (Hort. Malab. vol. vii. t. 33) which is the basis of D. triphylla, Linn. (Sp. Pl. ed. 1, p. 1032), we find it to be a Dioscorea with capsules longer than broad and with clavate, not spherical, axillary bulbils. In the case of Kattu-kelengu the account of the underground tuber accords with the characters met with in the tuber of $D$. Wallichii, though Rheede attributes to it properties more usually associated with the tubers of $D$. bulbifera; Linn. [1], a species which, though plentiful in Malabar, Rheede omits from his work. This circumstance suggests that the aerial tubers shown in the axils of the leaves of both Katu-katsjil and Kattu-kelengu, which agree with each other and with the aerial tubers of uncultivated $D$. bulbifera, may really have belonged to stems of the latter species which grew along with and were mistaken for those of $D$. Wallichii, Hook. f. This inadvertence, if it did take place, is easily explained. The flowering season of D. Wallichii is at the end of rains and therefore is considerably later than that of $D$. bulbifera, the leaves of which have largely disappeared, though the bulbils may remain attached to their bines, before the fruit of $D$. Wallichii has become so advanced as is shown in Rheede's figure of Katu-katsjil. We have, however, stronger evidence that the omitted $D$. bulbifera was confused with Kattu-kelengu in the circumstance that Rheede cites Carando as one of its synonyms. As Cooke has pointed out (Fl. Bomb. vol. ii. p. 758), Kadu-Karanda in Western India connotes the true uncultivated $D$. Bulbifera, Linn. The error of placing the aerial tubers of a Dioscorea which is bulbilliferous in the leaf-axils of one which is not, was no more reprehensible on the part of Rheede's artist than the parallel inadvertence in the case of Podava-kelengu (Hort. Malab. vol. vii. p. 97, tt. 51, 52) where fruits of Naravelia zeylanica are shown as arising from the axils of the leaves of $D$. hispida, Dennst. $\dagger$ The latter inadvertence has not prevented the recognition of what Podava-kelengu

* For the difference in the two renderings of this name the Hortus Malabaricus is responsible.

t The converse of this old East Indian error took place, at a much later date, in the West Indies. In 1858 Marsh collected in Jamaica and distributed as his n. 1709 a mixture of the leaves of Clematis dioica, Linn. and the fruiting panicles of Dioscorea martinicensis. This undetected mélange was inadvertently made by Grisebach the basis of $D$. triphylla, Griseb. (Flor. Brit. West Ind. p. 587); non. Linn. nec Jacq. (1.864). 
is, nor does it seriously impair the value of Rheede's figure, which has been cited bv Hooker (Flor. Brit. Ind. vol. vi. p. 289) under $D$. daemona, Roxb. The less serious inadvertence of adding the aerial tubers of $D$. bulbifera to the figures of the two sexes of another Dioscorea cannot prevent the citation of these figures under $D$. Wallichii, Hook. f., the species which, notwithstanding this error, they manifestly represent.* Since, however, one of these two figures is the basis of D. aculeata, Linn., published in 1753 , it follows that the name $D$. Wallichii, which was not published until 1892, must be subordinated to D. aculeata. For the moment, however, our interest is confined to the circumstance, already made clear by Hooker (Flor. Brit. Ind. vol. vi. p. 296) that neither Katu-katsjil nor Kattu-kalengu can be included in the aggregate $D$. sativa, Linn., as built up during the period $173 \%-67$.

In 1842 Grisebach described as D. sativa, Linn. (Flor. Bras. vol. iii. p. 43), a plant from Brazil which also differs from any of the elements included by Linnaeus in this species. The plant in question had been figured by Velloso in 1827 as $D$. heptaneura (Flor. Flum. vol. x. t. 124). Grisebach, unlike any of his predecessors from Willdenow onwards, was guided in his action by Lamarck; he excluded from $D$. sativa, Linn., everything save D. sativa. Linn. [1], the subject of Ehret's plate (Hort. Cliff.

* It may appear singular that an inadvertence so trivial as the addition to the figures of Kattu-Kelengu and Katu-Katsjil of the aerial bulbils characteristic of $D$. bulbifera should have obscured the identity of these plants longer than the more serious error of adding the fruits of a Clematid to the stem of a Dioscorea concealed the identity of Podava-Kelengu. Linnaeus became acquainted wilh that species through Rumph's figure of Ubium sylvestre (Herb. Amboyn. vol. v. t. 128) which he misidentified in 1754 (Amoen. Acad. vol iv. p. 131) with Rheede's Tajageri-Nuren, his own D. triphylla. But in none of his works did Linnaeus account for Podava-Kelengu. Burman (Hort. Malab. index) made no attempt to identify Podava-Kelengu in 1768. Roxburgh, who had received a plant from the Moluccas through C. Smith about the close of the eighteenth century, identified it with the Ubium sylvestre of Rumph, but failed to recognise its identity with Podava-Kelengu. In 1789 Lamarck (Encyc. Meth. vol. iii. p. 347) mistaking the Naravelia fruits for flowers, conjectured that it might be a Trichosanthes. Buchanan (afterwards Hamilton) who seems to have become acquainted with the plant itself during his Mysore journey in 1802-3, evidently without finding its fruit, thought it might be a Smilax. The plant is poisonous, hence Hamilton's names S. virose and S. narcotica, first made public in 1832 . In 1818, however, Dennstedt (Schl. Hort. Malab. pp. 15, 20, 33) recognised that Podava-Kelengu is a Dioscorea and named it D. hispida, Dennst. As this author has been careful at p. 33-the passage usually cited-to associate this name only with the first plate (Hort. Malab. vol. vii. t. 51) where no Naravelia fruits are shown, and as these fruits are not referred to in Rheede's text, $D$. hispida has to be regarded as the earliest unimpeachable one for the species, taking precedence over the name $D$. hirsuta employed by Blume in 1827 (Enum. Pl. Jav. p. 21) for Ubium sylvestre, Rumph. But Blume, like Dennstedt, recognised that Podava-Kelengu is a Dioscorea, which he named $D$. hirsuta inflorescentia monstruosa. This failure to reoognise the true explanation of Rheede's second figure (Hort. Malab. vol. vii. t. 52) does not detract from the merit of Blume as the first author to recognise that Ubium sylvestre and Podava-helengu are conspecific. Since then no one save Kunth in 1850 (Enum. vol. v. p. 438, footnote) has expressed any doubt on the subject. In 1841, by some inadvertence, Steudel (Nomencl. ed. 2, vol. i. p. 511) reduced $D$. hispida, Dennst., to $D$. cylindrica, Burm. (Flor. Ind. 215 [315]), which is in reality Ipomoea Batatas. This error has somehow crept into the Index Kewensis. 
t. 28); he believed that in $D$. heptaneura, Vell., he had at last found the missing species. But he did not accept the name D. Cliffortiana proposed by Lamarck in substitution for the original name D. sativa; he may have been influenced as regards this by his acceptance as correct of the erroneous statement made by Poiret that the plate showing two distinct species published by Lamarck (Ill. t. 818) to illustrate the genus Dioscorea was intended to be a portrait of the plant raised in 1737 in Clifford's garden at Hartekamp. There are other indications of haste in Grisebach's account of $D$. sativa. He states that in 1827 Presl had pointed out that an East Indian specimen named $D$. sativa in Willdenow's herbarium differs from the plant at that time, and still in Grisebach's day, grown in European gardens under the name $D$. sativa. There is no such statement in the passage by Presl to which Grisebach refers and the misquoted statement we have failed to trace. Grisebach indicates his belief that the specimen in question is $D$. deltoidea, Wall., which, as we learn from Sweet, had been introduced to European collections from Nepal in 1816.* If this identification be correct, the specimen cannot at the same time be Olus sanguinis, Rumph., $\dagger$ as Grisebach states. The error into which Grisebach had been led as to the identity of the Brazilian species was corrected by Kunth in 1850, when he described it once more as $D$. heptaneura, Vell. (Enum. vol. v. p. 326). In 1864 Grisebach accepted Kunth's view (Flor. Brit. West Ind. p. 588) and now intimated that the Brazilian D. sativa, Griseb. non Linn. (1842), was identical with D. lutea, Meyer (1818) and thus, though he does not say this, with $D$. sativa, Rodsch. non Linn. (1796). This may be the case, because Grisebach indicates that he had examined an authentic example of Meyer's species, whereas Kunth remarks (Enum. vol. v. p. 413) that the relationship of $D$. lutea remained doubtful to him. The point, however, still remains obscure owing to the fact that, so recently as $189 \%$, D. heptaneura, Vell. (1827), reduced by Grisebach in 1864 to $D$. lutea, Meyer, has been retained by Uline as a distinct species (Engl. Pfanzenfam. Nachtr. II.-IV. p. 86).

In 1845 Blanco employed the name D. sativa, Iinn. (Flor. Filip. ed. 2. p. 551) for a Dioscorea which in 1837 he had himself described as D. Tugui (op. cit. ed. 1. p. 800). Merrill in 1905 (Rev. Flor. Filip. Blanco, p. 87) was able to prove that D. Tugui, Blanco, is the plant which in 1850 Kunth (Enum. vol. v. p. 401)

\footnotetext{
* The name used by Sweet was $D$. nepalensis, which cannot be taken up owing to the absence of a description. It was not used for the first time, as Hooker suggests (Flor. Brit. Ind. vol. vi. p. 297), in 1830 (Sweet, Hort. Brit. ed. 2 , p. 522) but in 1827 (op. cit. ed. 1, p. 413) and must have been wellknown in collections even prior to its earliest publication, since we find it applied by Jacquemont in the field to a specimen of $D$. deltoidea, Wall., now in the Paris herbarium, which was collected by that distinguished traveller in the North-west Himalaya in 1829.

† In 1818 Meyer had already shown that this Amboyna plant ought to be excluded from $D$. sativa, Linn., but without stating that it is not a Dioscorea. In 1827 Presl pointed out the latter circumstance. Presl's statement was confirmed in 1847 by Blume, who pointed out (Rumphia, vol. iii. p. 207, t. 177) that Olus sanguinis is a Cardiopteris. In 1872 this conclusion was confirmed by Baillon (Adansonia, vol. x. p. 280) and is evident to anyone who may examine the figure.
} 
described as $D$. tiliaefolia, Kunth. But the plant of Blanco and Kunth is no more than a variety of the species to which Rheede's Mu-kelengu (Hort. Malab. vol. viii. t. 51) and the Cumbilium of Rumph (Herb. Amboyn. vol. v. t. 126) alike belong, although in 1753 Linnaeus referred the Malabar one to $D$. sativa $(S p . P l$. ed. 1. p. 1033) and in the following year placed the Amboyna one in D. aculeata (Amoen. Acad. vol. iv. p. 131).* D. sativa, Blanco (1845), is thus essentially the species to which in 1827 Blume intended to restrict the name 1$)$. sativa, Linn., and to which in 1839 Dillwyn succeeded in restricting it. Blanco's plant is therefore a form of $I$ ). sativa, Linn. [3].

In 1850 Kunth gave attention to $\bar{L}$ ). sativa (Enum. vol. v. p. 340). The species is not formallv stated by Kunth to be a doubtful one though his treatment indicates that it was such, because he has not provided a description; the account employed is taken verbatim from Blume (Enum. Pl. Jav. p. 23). The citations show that Kunth excluded from the Linnean aggregate J.). sativa, Linn. [1], [4], [5], [6], retaining only the Ceylon plant (Flor. Zeyl. n. 358) which is D. sativa, Linn. [2] and the $M u$-kelengu of Malabar, which is $D$. sativa, Linn. [3]. The transcript from Blume suggests that Kunth accepted Blume's description as applicable to these two plants but its inadequacy is shown by his citation of $D$. sativa, Blanco (Flor. Filip. ed. 2 . p. 551) which, while in reality conspecific with Mu-kelengu, so that the citation is justified, is at the same time identical with the plant described by Kunth himself as D. tiliaefolia (Enum. vol. v. p. 401). In quoting the plate prepared by Lamarck to illustrate the genus (Ill. t. 818), Kunth for the first time pointed out the sources of its two components, but he did not call attention to the fact that the portion borrowed from Gaertner depicts 7). sativa, Jinn. [4]. which Kunth had excluded from the species as understood by him, or advert to the circumstance that $D$. sativa, Ait. (Hort. Kew. ed. 2. vol. v. p. 392), which is cited in its entirety, really connotes 1). sativa, Linn. [4] and has only, by its reference to $M u$-kelengu, a casual connection with the species he was attempting to delimit. Various efforts have been made to follow Kunth. The citations employed by Miquel in 1859 (Flor. Ind.-Bat. vol. iii. p. 571) indicate one such attempt, but whether Miquel had in mind the plant to which Kunth endeavoured to restrict the name $D$. sativa, Linn., or rather had regard to the one to which alone the description given by Blume in 1827 applies, is not wholly clear. The use of the name D. sativa by Miquel in 1860 for a plant cultivated in

* The name used for the species by Hooker (Flor. Brit. Ind. vol. vi. p. 291) is $D$. spinosa, Roxb. The reasons given by Hooker for declining to employ either the name $D$. sativa or the name $D$. aculeata are incontrovertible. The difficulty with regard to the name adopted by Hooker is that there is an earlier 'D. spinosa, Burm. (Hort. Malab. index, p. 5) used by Burmann in 1768 for Rheede's Katu-Nuren-Kélengu (Hort. Malab. vol. vii. t. 34), which Linnaeus for some reason did not cite in 1753. This plant is clearly only a form of Nuren-Kelengu (op. cit. vol. vii. t. 35) which was referred by Linnaeus to his D. pentaphylla (Sp. Pl. ed. 1, p. 1032). It seems clear that in proposing the name $D$. spinosa for a Dioscorea with simple leaves Roxburgh had overlooked or had failed to become acquainted with the existence of the name D. spinosa, Burm. (1768). 
Sumatra (Flor. Ind.-Bat. Suppl. p. 2\%0) points, however, rather to the Javan species described by Blume than to the Malabar one figured by Rheede as the species intended, and this is strongly confirmed by the use of the name $D$. sativa by Miquel in 1865 (Prol. F'lor. Jap. p. 32) because we know that in this case Miquel intended, though he failed in his purpose, to connote the cultivated state of $D$. bulbifera, Linn. [1], for which Thunberg in 1784 had used the name $D$. sativa, Linn. In 1864, however, Thwaites (Enum. Pl. Zeyl. p. 326) interpreted Kunth's action as an attempt to confine the name $D$. sativa, Linn., to the plant figured by Rheede as Mu-kelengu. All the specimens from cultivated plants grown in Ceylon distributed by Thwaites as $D$. sativa, Linn., represent the plant which forms the subject of Rheede's plate. Perhaps the most interesting feature in Kunth's account of $D$. sativa, Linn., was his attempt, the first of its kind, to identify the various elements which he excluded from the species. For I). sativa, Linn. [1], he adopted the name D. Clif. fortiana, Lamk (Enum. vol. v. p. 337) and like Lamarck based this on the description by Linnaeus and the figure by Ehret of a plant or plants from the Hartekamp garden (Hort. Cliff. p. 459. t. 28). But he accepted under D. Cliffortiana the statement of Poiret that Lamarck's figure (Ill. t. 818) is meant to represent the species that the plate by Ehret is supposed to represent. He has been led further into the inconsistency of citing this plate both under $D$. sativa, Kunth, which it does in part represent, and under $D$. Cliffortiana which it does not represent even in part. It is true that Kunth points out that the portion of the plate borrowed by Lamarck from Gaertner shows a plant with fruits unlike those shown in Ehret's figure. But he does not point out that the fruit borrowed from Gaertner belongs to a species distinct from that represented by the flowering twig borrowed from Rheede, and as regards the latter, which represents the $M u$ kelengu of Malabar, Kunth says, under $D$. Cliffortiana, that it is a figure of a North American species.

Equal inconsistency is shown in the treatment of $D$. sativa [4], the West Indian plant taken up by Linnaeus from Plumier. Burmann's figure ( $\mathrm{Pl}$. Amer. Plum. t. 117. fig. 1) he regarded as the authority for the species which he nevertheless identified with $D$. altissima, Lamk, a name the basis of which is the companion figure on the same plate. But in another passage (Enum. vol. v. p. 356) he has cited fig. 1 under $D$. piperifolia, Willd. vix Humb. \& Bonpl., and in yet another (Enum. vol. v. p. 412) has cited fig. 2, accurately, under I). altissima, Lamk. By inadvertence Kunth says that Gaertner had quoted fig. 2 where in reality he has referred to fig. 1 ; at the same time he omits to state that Gaertner's own figure (Fruct. t. 17. fig. 4) represents Plumier's plant.

Kunth has omitted to identify $D$. sativa, Linn. [5], the West Indian plant taken up by Linnaeus from Sloane, and although he has alluded to the discrepant views of Presl and Grisebach regarding the Amboyna plant which is D. sativa, Linn. [6], he has overlooked the identification of this plant by Blume in 1847 and has expressed no opinion of his own as to what it really is.

In 1864 these identifications by Kunth were revised by Grise- 
bach (Fl. Brit. West Ind. p. 588). Again D. sativa, Linn. [1], was treated as D. Cliffrotiana, Lamk, but accepted as probably a form of $D$. villosa, Linn., the authority cited being Ehret's figure (Hort. Cliff. t. 28) but not the text which corresponds. The Ceylon plant (Flor. Zeyl. n. 358) which is D. sativa, Linn. [2], has not been alluded to by Grisebach. The Malabar plant, which is $D$. sativa, Linn. [3], is accepted as the basis of the Linnean species.

The West Indian plant taken up from Plumier, which is $D$. sativa, Iinn. [4], and which was said by Kunth to be D.altissima, Lamk, is identified by Grisebach with D. multiflora, Presl, a species described in 1844. Though the identification in this instance is accurate it is not adequate, there being an older name for the species which was published by Sprengel in 1822, and there being another $D$. multiflora, Mart., published by Grisebach himself in 1842. The other West Indian plant, taken up from Sloane, which is D. sativa, Linn. [5], has been identified by Grisebach with $D$. altissima, Lamk. This identification cannot be accepted; Sloane's plant, the Volubilis nigra, radice tuberosa compressa maxima digitata farinacea esculenta is the well-known "Negro Yam, of the West Indies, whereas 1). altissima, Lamk, is Plumier's Polygonatum scandens altissimum, foliis tamni with, as its original reference to the genus Polygonatum as contrasted with Dioscorea implies, an elongated and nodose rhizome, not a digitate tuber. The figure of D. altissima (Burm. Pl. Amer. Plum.t. 117. fig. 2) shows moreover that its leaves have stipulary prickles; there are no such prickles in the 'Negro Yam' though the stem low down may be armed.* But Grisebach's treatment of $D$. altissima is not wholly consistent; on the previous page (l.c. p. 587) he referred it tentatively to $D$. alata, Linn.. which is the true 'Yam' as opposed to the 'Negro Yam' of the West Indies.

In dealing with D. sativa, Linn. [6], which he terms " the contested plant quoted from Rumph," Grisebach has neither

* We take this opportunity to publish in full Plumier's description of the plant which in 1789 became the basis of $D$. altissima, Lamk (Encyc. Meth. vol. iii. p. 231) :-

Polygonatum scandens altissimum foliis tamni. Plumier MSS. tom. iii.

Radix hujus plantae arundinacea est nodosa scilicet geniculata et fibris duris tota compacta, cauliculum unicum ut plurimum emittens altissime scandentem, lignosum, teretem, virentem et nodosum unde plurimae longissimae viticulae tenues diffunduntur etiam nodosae et ad singulos nodos binis foliis oppositis instructae cordatis membranaceis desuper e viridi lucentibus inferius vero paulo dilutioribus nervulisque instructis ut in plantagine vulgari a pediculo ad apicem percurrentibus inter quos venulae aliae jacent exiguae undulatae ac veluti parallelae. Singula folia palmam manus circiter sunt ampla pediculoque innituntur longiusculo et ad initium duobus apiculis mollibus instructo ex pediculorum autem alis longus propendit funiculus per totam longitudinem floribus instructus exiguis ipsi funiculo adpositis monopetalis campaniformibus tubulatis calycis expertibus sexque acuminibus dissectis deforis viridantibus et tomentosis, intus vero lutescentibus punctulis rubentibus signatis, tribusque apicibus subrotundis et virentibus stipatis.

Fructus maturos non vidi; plantam reperi junio apud insulam martinicensem. 
attempted to identify the species nor alluded to the fact that Blume had already done so in 1847.*

In 1861 the name D. sativa was applied by Bentham (Flor. Hong Kong. p. 368) to that one of the two species included by Linnaeus under 1). bulbifera which has capsules longer than broad and has seeds winged only at the top. In deliberately adopting this view Bentham does not appear to have been influenced by the circumstance that this usage had already been adopted by Thunberg in 1784, or to have considered the possibility that it was perhaps but a continuation of that followed by Blume in 1827, Hasskarl in 1844, and Miquel in 1859 and 1860. Apparently Thunberg identified this species with $D$. sativa because he found it cultivated in Japan as a crop. Bentham on the other hand did so because he regarded the plate by Ehret, published in 1737 (Hort. C'liff. t. 28) to be the basis of $D$. sativa, Linn., and because he considered this plate, which shows capsules that are longer than broad, a passable representation of the species with which he was dealing. He was, he has informed us, further actuated by a belief that the Linnean names $D$. sativa and $D$. bulbifera had been transposed by nearly all modern botanists. $\dagger$

In 1865 the name $D$. sativa was employed by Miquel (Prod. Flor. Jap. p. 323) to designate a Japanese species which he believed to be the plant named $D$. sativa by 'Thunberg in 1784 . The sheets written up by Miquel show that some of the specimens so named are actually referable to Thunberg's species, which is $D$. bulbifera, Linn. [1]. But the bulk of the material belongs to another suecies unknown to Thunberg. In 1879 Franchet \& Savatier (Enum. Pl. Jap. vol. ii. p. 47) followed Miquel in this use of the name for a combination of two species. It was not until 1889 that the confusion created by Miquel and continued by Franchet was remedied; the species which these authors had in view was then adequately differentiated and characterised by Makino as D. tokoro (Tokyo Bot. Mag. vol. iii. p. 112 and $I l l$. Flor. Jap. t. 24).

In 1887 Trimen, in his concordance to the Ceylon herbarium of Hermann and the Flora Zeylanica of Linnaeus, had to point out (Journ. Linn. Soc. Bot. vol. xxiv. p. 151) that the plant collected by Eermann which is the authority for the citation by Linnaeus (Flor. Zeyl. n. 358) is Tinospora cordifolia, Miers. Trimen has

* Before leaving the subject of $D$. sativa, Kunth, it may be noted that while Kunth has pointed out the existence of $D$. sativa, Bowdich (Excurs. Mad. p. 115) which is a Tamus, and of D. sativa, Sieber (Cat. Pl. Aegypt.) which is an Anredera, he has not alluded to D. sativa, Thunb. (1784) from Japan, or D. sativa, Bunge (1831) from China, or D. sativa, Herb. Madr. ex Wall. (1832) from Travancore, all of which are species of Dioscorea.

$\dagger$ A sequel to this belief of Bentham has been another formed by Hooker, that $D$. bulbrfera, Linn., is unrecognisable (Flor. Brit. Ind. vol. vi. p. 296). The expression of these beliefs has given rise to a controversy which can be best examined when the incidence of the name $D$. bulbifera, as employed by Linnaeus and subsequent writers, is being discussed. The necessary examination the writers hope to make in another note. Since 1861 the usage advocated by Bentham was repeated by himself in 1873 (Flor. Austral. vol. vi. p. 461); by Hooker in 1892 (F'lor. Brit. Ind. vol. vi. p. 295), by Uline in 1897 (Engl. Pflanzenf. Nachtr. II.-IV.p. 84), and again by Hooker in 1898 (Trimen Handb. Flor. Ceyl. pars iv. p. 461). 
there assumed that "Linnaeus must have been well acquainted with $D$. sativa and his reference to it of these specimens of the very different 'Rasa-kinda,' Tinospora cordifolm, must be regarded as an inadvertence." The specimens have been the subject of other inadvertences. In 1893 Trimen himself became responsible for one of these in his statement (Handb. Flor. Ceyl. pars i. p. 40) that Linnaeus referred the specimens to the species which in 1753 he named $D$. alata; this is not the case, the citations under D. alata (Sp. Pl. ed. 1. p. 1033) are in the work of 1747 given under the next succeeding one (F'lor. Zeyl. n. 359). Again in 1898 Hooker, overlooking the fact that the specimens in question (F'lor. Zeyl. n. 358) had already been dealt with under Tinospora cordifolia, repeated their citation under $D$. sativa (Handb. Flor. Ceyl.. pars iv. p. 278).

The subjoined brief summary of the results of our bibliographical study, checked by an examination of such herbarium material as is available, shows how the name $D$. sativa has been employed by various authors since 1753 .

Conspectus of us age of the name D. Sativa, Linn.

D. sativa, Linn. (1753) includes D. sativa [1] [2] [3] [4] [5];

D. sativa, Linn. (1754) is applied to I). sativa [6];

D. sativa, Linn. (1759) includes D. sativa [1] [2] [3] [4] [5] [6];

D. sativa, Burm. (1768) includes D. sativa [1] [2] [3] [4] [5] [6];

D. sativa, Mill. (1768) is restricted by description and geography to $D$. sativa [4];

D. sativa, Thunb. (1784) is applied to D. bulbifera, Linn. (1753) [1];

D. sativa, Gaertn. (1788) is restricted by description and illustration to $D$. sativa [4];

[D sativa,] Lamk (1789) is restricted to D. sativa [1] and employed as a synonym of the newly proposed name $D$. Cliffortiana, I.amk (1789);

D. sativa, Rodsch. (1796) is applied to a Guiana plant afterwards described as D. lutea, Meyer (1818);

D. sativa, Willd. (1806) includes $D$. sativa [1] [2] [3] [5] [6] while [4] is omitted;

D. sativa, Ait. (1813) is restricted by geography to D. sativa $[4]$;

D. isativa, Sieb. (1821) is applied to a species of Anredera.

D. sativa, Poir. (1823) is restricted by illustration to D. sativa [3] [4] but is by inadvertence treated as a synonym of $D$. sativa [1] under the name $D$. Cliffortiana, Lamk (1789);

D. sativa, Bowd. (1825) is applied to a Tamus of Madeira.

D. sativa, Presl (1827) is applied to a Peruvian plant whose identity is not known, but which may be allied to $D$. lutea, Meyer (1818);

D. sativa, Blume (1827) is applied to a Javanese plant whose identity is uncertain, but which may be $D$. bulbifera, Linn. [1]; 
D. sativa, Maycock (1830) is applied to the unarmed condition of D. sativa, Linn. [5];

D. sativa, Bunge (1831) is applied to D. opposita, Thunb. (1784);

D. sativa, Rottler (1832) is applied to 1). bulbifera, Linn. [2] (1753) afterwards described as $D$. Wallichii, Hook. f. $(1 \overrightarrow{892})$;

D. sativa, Dillwyn (1839) is restricted by citation to D. sativa $[4]$;

D. sativa, Griseb. (1842) is applied to the Brazilian D. heptaneura, Vell. (1827);

D. sativa, Blanco (1845) is applied to a form of D. sativa [4];

D. sativa, Kunth (1850) is restricted in intention to $D$. sativa [2] [3], though Kunth's citation of Blume involves the probable inclusion of $D$. bulbifera $[1]$, while $D$. sativa [1] is kept apart as a synonym both of D. quaternata, Walt. (1788) and of $D$. C'liffortiana, Lamk (1789);

D. sativa, Benth. (1861) is restricted to $D$. sativa [1] which is treated as identical with D. bulbifera, Linn. [1] (1753);

$D$. sativa, Griseb. (1864) is treated as a synonym of $D$. lutea Meyer (1818) which is now considered to be identical with D. heptaneura, Vell. (1827);

D. sativa, Thw. (1864) is deliberately confined to $D$. sativa $[4]$;

D. sativa. Miq. (1865) is applied mainly to a Japanese plant afterwards described as $\mathrm{Z}$. tokoro, Makino (1889).

D. sativa, Hassk. (1867) is restricted by citation to D. sativa [4].

When the question as to the identity of the six different plants included by Linnaeus under D. sativa in 1753 and 1754 is considered regard must be had to the conclusion of Lamarck in 1789, Grisebach in 1842, Bentham in 1861 and Hooker in 1892 that the figure by Ehret published in 1737 (Hort. Cliff. t. 28) must be accepted as the authority or basis for the name, and to the fact that the only authors who have taken a different view have been possibly Blume in 1827* and certainly Kunth in 1850 . As Kunth has, in intention at least, restricted the use of the name to the plant especially cited by Blume, which is the Malabar $M u$-kelengu of Rheede, it is desirable to defer the consideration

* Rottler, whose tentative use of the name $D$. sativa in the Madras herbarium has been adopted by Wallich, may have held the view that $D$. sativa should be restricted to a single plant among the six included under the name by Linnaeus; so, for anything they say, may Thunberg, Bunge and Miquel. As, however, all four authorities have used the name D. sativa for species which lie outside the Linnean aggregate, their views may be neglected here. The case of Blume is on a somewhat different footing, in the first place because he believed himself to be using the name for a single species which is included in the Linnean aggregate, and further because Kunth, by transcribing the definition drawn up by Blume, has indicated fairly clearly that he was guided by Blume's judgment in his selection of the particular Linnean element of $D$. sativa to which that name should be restricted. The fact that the plant actually described by Blume cannot possibly be the Linnean element in question, or indeed be any of the six species included in $D$. sativa by Linnaeus, does not affect the manifest intention of Kunth, which was anticipated by Dillwyn in 1839 and to which logical effect was given by Thwaites in 1864 and by Hasskarl in 1867. 
of Rheede's and Ehret's figures until the remaining four plants have been disposed of.

Of the four plants in question two are from the East Indies as understood by Linnaeus; the other two are West Indian species. The former are (1) a Ceylon plant collected by Hermann and published on his authority as Rasa-kinda or Rossa-kinda, which forms the basis of one of the Linnean citations (Flor. Zeyl. n. 358) under D. sativa in 1753 (Sp. Pl.ed. 1. p. 1033); and (2) an Amboyna plant figured by Rumph as Olus sanguinis, which was referred by Linnaeus to $D$. sativa in 1754 (Amoen. Acad. vol. iv. p. 133). Both of these Asiatic plants exclude themselves from $D$. sativa, however it may ultimately be decided to apply that name, because neither of them belongs to the genus Dioscorea. The Ceylon plant is a species of Tinospora (Trim. Journ. Linn. Soc. Bot. vol. xxiv. p. 151); the Amboyna plant is a Cardiopteris (Blume, Rumphia, vol. iii. p. 207. t. 177). The two West Indian plants are both members of the genus Dioscorea; they are (1) a Martinique wild plant first recorded by Plumier and named by him Dioscorea scandens foliis tamni, fructu racemoso: and (2) a Jamaica cultivated plant named by Sloane Volubilis nigra radice tuberosa compressa maxima digitata farinacea esculenta folio cordato nervoso. With the earliest citation of the Martinique species in 1703 Plumier published a plate showing the fruit (Gen. p. 9. t. 26); the main-figure by Plumier of the same plant was published in 1755 by Burmann (Pl. Amer. Plum. t. 117. fig. 1). The actual specimen which is the basis of Sloane's diagnosis of 1696 (Cat. Jam. p. 46) is still in the Sloane herbarium. A comparison of the material in herbaria tallying with the figure by Plumier and the specimen of Sloane respectively, shows that the Martinique plant twines to the left and has reflexed capsules, whereas the Jamaica plant twines to the right and has forward-pointing capsules; the leaves of the Jamaica plant, moreover, while very often alternate on secondary branches are opposite on the main bines and on most primary branches, those of the Martinique plant are always alternate; the flowers, too, differ considerably, those of the Martinique plant have membranous bracts and bracteoles and a membranous perianth with only three fertile stamens alternating with three staminodes, the anther-cells being discrete, ${ }^{*}$ whereas those of the Jamaica plant have firm almost hyaline bracts and bracteoles, a thick and somewhat fleshy perianth with six fertile stamens, the anther-cells being contiguous. There is therefore no question that the two West Indian plants included by Linnaeus under $D$. sativa belong to two distinct species.

The species figured by Plumier was transferred by Willdenow in 1806 to D. piperifolia, Humb. and Bonpl. Willdenow's treatment was followed by Poiret in 1813 (Encyc. Meth. Suppl.

* The original Plumierian drawing (MSS. tom. ii. n. 144) includes some at least of the analytical details contained in Plumier's plate of 1703 (Gen. t. 26). These were not made use of by Burmann (Pl. Amer. Plum. t. 117, fig. 1) possibly owing to their having already been published. In the original drawing, underneath the figures of the male flower, we find the legend 'fleur blanche, en clochette, découpée en 6 parties, 3 étamines à double teste.' 
vol. iii. p. 138), by Presl in 1827 (Rel. Haenk. fasc. 2. p. 134), and by Grisebach in 1842 (Flor. Bras. vol. iii. p. 27). So far these references had regard only to Plumier's illustration. Kunth's treatment of this plate under $D$. sativa has already been adverted to; in another place (Enum. vol. v. p. 336) he did expressly exclude Plumier's plant from $D$. piperifolia, but he did not even there definitely identify it with a known species. It is to Grisebach that we owe the reference of the plant figured by Plumier to a properly characterised species, though his treatment still leaves something to be desired. In 1864 (Flor. Brit. West Ind. p. 587) he identified it with a Martinique plant which Presl had named D. multiflora in 1844 (Bemerk. p. 116), overlooking when he did so that he himself had already published a different $D$. multiflora, Mart., in 1842 (Flor. Bras. vol. iii. p. 35).*

The bibliographical history of this Martinique plant has been rather chequered. The plant was collected by Kohaut on behalf of Sieber and was issued by the latter, at first without a specific name (Herb. Mart. n. 27), in 1821. A specimen which reached Sprengel was described by that author in 1822 as $D$. martinicensis (Neue Entdeck. vol. iii. p. 17). $\dagger$ Shortly afterwards Sieber himself issued a list in which it was identified with $D$. altissima, Lamk (Herb. Maṛt. Suppl. n. 27). In 1825 Sprengel accepted this determination and treated his D. martinicensis as identical with D. altissima, Lamk (Syst. vol. ii. p. 153). Presl in 1844 recognised the error, but unfortunately overlooked the existence of the name $D$. martinicensis, Spreng. (1822) for the species he was describing and of the name $D$. multiflora, Mart. (1842) for another species. Kunth in 1848 while overlooking the former inadvertence detected the latter; to remedy it he suggested that the Martinique plant be termed D. Sieberi (Act. Acad. Berol.

* The difficulty caused by the existence of the name $D$. multiflora in connection with two distinct species was pointed out in 1916 by Hauman (Anal. Mus. Nac. Hist. Nat. Buenos Aires, vol. xxvii. p. 458, footnote).

† That the Martinique plant of Plumier is the same as the Martinique plant of Sieber is evident from a comparison of Kohaut's specimens with Plumier's plate and is confirmed by the comparison of Plumier's original description, here reproduced, with those of Sprengel and Presl and Kunth. Plumier's account is as follows :-

Dioscorea scandens foliis tamni fructu racemoso Plumier MSS. tom. ii. fig. 144 .

Huiusce planta radix radicis Bryoniae vulgaris in modum carnosa non napiformis quidem sed in ramos et in appendices distenta, tenera candida multoque sapore conspicuo donata. Cauliculum unicum producit tenuissimum sed lentum alteque supra vicinas arbores scandentem et ramos plurimos emittentem etiam longissimos et tenuissimos quibus inhaerent ampla folia cordata tamni vulgaris foliis perquam conformia sed ampliora, nervosiora, obscurius aliquantulum virentia et amariuscula longis annectuntur pediculis longus appendet floribus onustus exiguis candidis monopetalis campaniformibus patentibus et in sex segmenta divisis, ac senideni tribus staminulis bicipitibus instructis. Ex calyce autem perquam exiguo surgit pistillum quod infimam floris partem perfodit abitque deinde in fructum trigonum et in tria loculamenta multum compressa et fere semicircularia divisum, seminibus foeta planis orbiculatis et marginatis et amarissimis.

Multoties plantam reperi variis in locis insulae martinicanae potissimum in illa regioue quae vulgo le Mont Hoel dicitur ad partes arcis Divo Petro dicatae. 
1848 p. 58). Kunth had not then decided to establish his genus Helmia for those species of Dioscorea in which the seeds are winged only at the top. When he took this step, D. multiflora, Mart. (1842), automatically became Helmia multiflora, Kunth (Enum. vol. v. p. 431), and the name D. multiflora, Presl (1844), once more became available (Enum. vol. v. p. 333). When in 1864 Grisebach pointed out the identity of this Martinique plant with the subject of Plumier's plate he did, however, introduce a minor confusion owing to his having described as D. triphylla, Linn. (Flor. Brit. West Ind. p. 587)* what as regards foliage is Clematis dioica, Linn., and as regards the compound fruiting spikes is $D$. martinicensis, Spreng.

So far as may be judged from the specimens preserved in the collections at Kew and the Natural History Museum, London, the plant known as D. martinicensis, Spreng., is confined to the West Indies. It is a member of the section Lychnostemon, and within that section is most nearly allied to D. meridensis, Kunth, a species from Colombia with leaves equally ctosely reticulated and with the inflorescences similarly branched. But while so like $D$. martinicensis, the Colombian plant is readily distinguished from the West Indian one by being everywhere puberulous. Plentiful in Martinigue and St. Vincent, $D$. martinicensis is equally abundant in Jamaica. $t$ In Dominica the

* Grisebach's account of D. triphulla is perplexing in other ways; he states that his conglomerate plant is " naturalised in Jamaica." There is no such statement on the sheet of March n. 1709, which G irisebach has written up as D. triphylla, Linn. Grisebach's account of the Clematis leaves and of the Dioscorea capsules is accurate: to what plant the citation " 3 stamens fertile" may apply, is not clear. The citation of the plate of $D$. triphylla of 1793 by Jacquin (Ic. Pl. Rar. t. 627) at first suggests that the species Grisebach had in mind was D. triphylla, Linn. of 1754 (Amoen. Acad. vol. iv. 131), which is D. hispida, Dennst. (1818), rather than the D. triphylla, Linn. of 1753 (Sp. Pl. ed. 1, p. 1032) which, as Linnaeus anticipated when he first published this name, now proves to be only a form of $D$. pentaphylla, Linn. Against this, however, is the fact that the $D$. triphylla figured by Jacquin has 6 fertile stamens, and that the good description of the fruit of this species by Gaertner (Fruct. vol. i. p. 66) does not in the least agree with Grisebach's account of the capsules of the West Indian plant. The other $D$. triphylla, Linn., which is but a form of D. pentaphylla, has, it is true, only 3 fertile stamens. But in this case again the fruits are quite unlike those described by Grisebach. Moreover, neither the D. triphylla, Linn. of 1754 , nor the $D$. triphylla, Linn. of 1753 , are naturalised in Jamaica. The only $D$. triphylla of which this might perhaps be said, is the $D$. triphylla described by Poiret in 1813 (Encyc. Meth. Suppl. vol. iii. p. 140). The name $D$. triphylla, Poir., however, is merely a typographical error for $D$. trifida, Linn. f., a species described in 1781 by the younger Linnaeus (Suppl. Pl. p. 427 -not p. 224 as stated by Poiret, l.c.) from a specimen collected by Allamand in Surinam, which still exists in the Linnean herbarium. This species was described again in 1789 by Lamarck as D. triloba (Encyc. Meth. vol. iii. p. 234), and once more in 1806 by Willdenow as D. brasiliensis ( $S p$. Pl. ed. Wi!ld. vol. iv. p. 791).

+ Though so common. in Jamaica the species is not dealt with by Sloane. It is the Wild Yam of P. Browne (Nat. Hist. Jam. p. 360) who adverts to its relatively large capsules, as compared with those of the Yam (D. alata, Linn.) and the Negro Yam (D. cayenensis, Lamk), the only other species which Browne deals with. Browne cites under it Dioscorea foliis cordatis caule laevi of the Hortus Cliffortianus (D. sativa, Linn.), but by inadvertence cites also the Fegopirum scan iens seu volubilis nigra majus of Sloane (Cat. 46 : Nat. Hist. Jam. vol. i. p. 131, t. 90, fig. 1) which is Anredera scandens, Moq. (Grisebach, Flor. Brit. West Ind. p. 60). 
place of $D$. martinicensis is taken by a Dioscorea, known there as the 'Yam Poule,' with leaves that in shape and size resemble those of the Martinique and Jamaica plant, but differ in being widely reticulated and in subtending simple spikes. This plant is included by Grisebach in D. multrflora, Presl, which is D. martinicensis, Spreng. By others it is included in D. polygonoides, Humb. and Bonpl., a South American species, and it may perhaps be identical with the unnamed plant that has been attached in the Linnean herbarium to the one there written up as $D$. sativa. But it is certainly not the species accepted by Kunth as $D$. polygonoides and cannot even be regarded as a variety of Kunth's plant so named. Whether the 'Yam Poule" be specifically distinct from $D$. martinicensis or not is a point that can only be settled when the two are grown experimentally side by side. Even if it should prove to be referable to Sprengel's plant it must be regarded as a very marked variety.

The history of the second West India species included by Linnaeus under $D$. sativa has not been quite so complicated as that of $D$. martinicensis, Spreng. It was taken up by Linnaus from Sloane's accounts of 1696 (Cat. p. 46) and 1707 (Hist. Jam. vol. i. p. 140). In the latter work Sloane terms this the Negro Countrv Yam, as opposed to the Yam or Yammes proper (D. alata, Jinn.); by his remark 'swine are fatted with these roots in Zeylan,' Sloane shows that he took it to be a species grown in Ceylon, 'ubi porci cum radicibus saginantur' which Commelin believed to be the Mu-kelengu of Kheede. Linnaeus, who had not seen a specimen of the 'Negro Yam,' appears to have regarded Sloane's surmise as an ascertained fact, hence his reference to the same species of two plants so dissimilar as the Mu-kelengu of Malabar and the Negro country Yawi of Jamaica. P. Browne in 1756 also terms Sloane's plant the 'Negro Yam,' but by his citation under this name of Dioscorea foliis cordatis caule tereti aculeato bulbifero shows that he did not agree with Linnaeus and that he considered it to be more naturally placed in D. aculeata, Linn. than in D. sativa, Linn. Since the stems of the Negro Yam are very often armed low down, this judgment was a natural one on the part of an author thoroughly familiar with the plant as it grows, who had no apparent anxiety to establish a new species. After Browne, however, little attention seems to have been paid to this plant. Lamarck, and other subsequent writers, expressly or implicitly excluded Sloane's plant from $D$. sativa, but no one after Browne attempted to identify the plant of Sloane until Grisebach in 1864 hazarded the suggestion that it is $D$. altissima, Iamk. An examination of Sloane's original specimen shows that it represents the species which is still known in Jamaica as the ' Negro Yam.' This species was described for the first time in 1789 by Lamarck as D. cayenensis* (Encyc. Meth. vol. iii.

* The 1rame cayenensis was inadvertently printed cajennensis by Willdenow in 1806 (Sp. Pl. ell. Willd. vol. iv. p. 791). This was changed to cayennensis by Sprengel in 1825 (Syst. vol. ii. p. 152), and his orthography has been followed by Grisebach, Kunth and others. There is nothing to show why Sprengel, when correcting one of Willdenow's typographical errors, should have accepted the other. Attention was directed to the correct spelling in the Irudex Kewensis in 1893, but with little result; the erroneous Sprengelian form was again adopted by Uline in 1896 (Engl. Bot. Jahrb. vol. xxii. p. 431). 
p. 323), and in another form was redescribed by Poiret in 1813 as D. rotundata (Encyc. Meth. Suppl. vol. iii. p. 139). Maycock in 1830 regarded the armed and the unarmed conditions of $D$. cayenensis as specifically distinct, treating the former as $D$. aculeata, Linn., and the latter as D. sativa, Linn. (Flor. Barbad. pp. 389, 390). According to Grisebach (Flor. Brit. West Ind. p. 587, the species described by Kunth in 1850 as D. Berteroana (Enum. vol. v. p. 381) is also D. cayenensis. According to Kunth, Balbis had formally proposed the adoption of P. Browne's determination of 1756 and had named the species D. aculeata. Kunth appears to have doubted whether the $D$. cayenensis described by Grisebach in 1842 (Flor. Bras. vol. iii. p. 33) be really the species described by Lamarck, and the statement by Grisebach that in his plant the stamens are attached at the apex of a corolla tube certainly justified Kunth's caution. On the other hand the agreement in other respects, and particularly the reference by. Grisebach to an error in the original description, which shows that the firm and glistening bract and bracteoles were mistaken by Lamarck for a calyx, render it probable that Grisebach's plant is really that of Lamarck. Grown largely, as its name implies, in former days to provide food for Negro slaves in the West Indies and in South America, it is possible that this plant may not be a native of the New World, but may have been shipped from Africa as food* for those who had to endure the horrors of the middle passage and did not all survive. In 1896 Uline definitely claimed it as an Old World plant. It certainly is not Asian, and if it be African-it is very closely allied to the African $D$. prehensilisDline has not indicated where or by whom it has been collected

- Clusius has referred in 1601 (Rar. Pl. Hist. lib. iv. p. lxxix.) to a specific instance of this practice. A consignment of slaves purchased in the island of S. Thomé, off the Gaboon coast, in 1596, was being shipped to Lisbon for resale. The ships on which the slaves were to be sent all came to Walcheren in Holland. Through Parduyn, a burgess, and Roëls, a physician of Middelburg, Clusius obtained specimens of the Dioscorea tubers intended as food for these slaves on the voyage. Clusius found that they were of two sorts. His account of them is interesting, but unluckily bis evidence is negative so far as the origin of $D$. cayenensis is concerned. One kind had the name Igname or Inhame; the description tallies with that of some race of D. alata, Linn. In 1648 there appeared a description by Marcgraf. under the name Inhame de S. Thome, of $D$. alata as grown in Brazil. We may therefore feel certain that this Inhame of Clusius really was the 'Greater Yam.' But the 'Greater Yam' originated in Asia and all we learn from Clusius is that by the end of the sixteenth century this Asiatic species had reached West Africa. The second kind was also termed Inhame by the Portuguese merchant who handed the tubers to Parduyn. But Clusius had learned somehow that others termed this second kind Ycam Peru. Ycam is an African name for an edible Dioscorea. But while it may be assumed that those who used the name were aware of this fact, the qualifying term shows that in their judgment the plant was not the African species to which the name properly belongs but an exotic which they believed, rightly or wrongly, to be a native of South America. The African Akam is D. latifolia, Benth., a Yam nearly allied to, if not indeed a variety of D. bulbifera Linn. The name has reached the West Indies, where the cultivated $D$. bulbufera is known as Acom. But both in Africa and in the New World Ycam or Akam or Acom connotes a member of the section Opsophyton and is not applied to any species of the section Enantiophyllum, to which both D. alata and D. cayenensis belong. 
on the Dark Continent. As Uline (Engl. Nat. Pfanzenfam. Nachtr. II.-IV. p. 85) uses the name D. spinosa, Roxb., for the Ceylon plant, referred to by Commelin, which Sloane supposed to be the Negro Yam, his judgment regarding the Old World origin of $D$. cayenensis should rest on some basis other than that which influenced Sloane and misled Linnaeus.

When we come to the Malabar plant figured by Rheede as Mu-kelengu we have to deal with another complication. The authors who have cited Rheede's figure under $D$. sativa. Linn. include some, like Burmann in 1768, Willdenow in 1806 and Presl in 1827, who have treated the plant it represents as merely one form of a more or less variable species; and others, like Gaertner in 1788, Aiton in 1813, Blume in 1827 and Kunth in 1850 , who by their descriptions or by some other indication, have shown a desire to confine the name $D$. sativa, Linn. to a single well-characterised form. The species with which Gaertner and Aiton believed Mu-kelengu to be conspecific we now know to be the West Indian D. martinicensis, Spreng.; that with which Blume identified $M u$-kelengu we believe to have been $D$. bulbi fera, Linn. [1]. In the case of Kunth the intention to restrict the name $D$. sativa to the Mu-kelengu of Rheede (Hort. Malab. vol. viii. p. 97. t. 51), though not satisfactorily carried out, is very manifest. At last in 1864 the limitation aimed at was definitely accomplished by Thwaites (Enum. Pl. Zeyl. p. 326, note). However, as Hooker has shown, the name D. sativa cannot be used for the species represented in Rheede's figure of Mu-kelengu, notwithstanding the citation of that plate by Iinnaeus, because the figure bv Ehret (Hort. Cliff. t. 28) cited by Linnaeus in 1753 must be accepted as the basis of $D$. sativa, Linn. (Flor. Brit. Ind. vol. vi. p. 291).

This, however, is not the only point connected with the plant now being considered in respect of which we are indebted to Hooker. To him we owe the recognition in 1892 for the first time of the important fact, overlooked by Linnaeus, that the Mu-keleng'u of Rheede is conspecific with the plant figured by Rumph as Combilium (Herb. Amboyn. vol. v. p. 35\%. t. 126). As a result of this oversight Linnaeus in 1754 (Amoen. Acad. vol. iv. p. 131) instead of referring the Amboyna plant to $D$. sativa, referred it to his own $D$. aculeata, Linn. (Sp. Pl. ed. 1. p. 1033), * from which it differs in having stems which twine to the left instead of the right and in having simple in place of paniculate male spikes. The confusion thus introduced into the conception of $D$. aculeata, Linn., has been closely parallel with that inherent in the conception of $J$. sativa, Linn. Incorporated by Linnaeus in $D$. aculeata in his later writings, we find Combilium accepted under that species by Burmann in 1768 (Flor. Ind. p. $214[314]$ ). Dealing with D. aculeata, Linn., in

* The name $D$. aculeata, as used in 1753 , is based primarily on the citation Dioscorea foliis cordatis caule aculeato bulbifero (Hort. Cliff. p. 459), and as in 1737 this phrase was applied only to the Kattu-Kelengu of Rheede (Hort. Malab. vol. vii. p. 71, t. 37) the incidence of the name $D$. aculeata is, as Hooker has shown (Flor. Brit. Ind. vol. vi. p. 296), definitely limited to the species figured under that name. Unfortunately the identity of the KattuKelengu was still doubtful to Hooker in 1892. 
1789, we find Lamarck (Encyc. Meth. vol. iii. p. 232) providing a description that is strictly confined to the C'ombilium of Rumph. in 1793 Loureiro (Flor. Cochinchin. p. 768) supplied an original description of what may very well be a form, as he says, of Combilium. Willdenow in 1806 (Sp. Pl. ed.' Willd. vol. iv. p. 792) included like Burmann both the $D$. aculeata, Linn., of 1753 and the D. aculeata, Linn., of 1754. By their citations or their geographical indications, or both, we find that Persoon in 1807 (Syn. vol. ii. p. 601) and Sprengel in 1825 (Syst. vol. ii. p. 152) did the same. In 1827 Blume (Enum. Pl. Jav. p. 23) repeated the treatment of Willdenow and Sprengel, and in 1850 Kunth (Enum. vol. v. p. 398), to whom the species remained an altogether doubtful one, which he admitted himself unable to classify, accepted $D$. aculeata exactly as Blume had left it.

In a note following his account of D. aculeata, Linn., Kunth calls attention to D. aculeata, Roxb. (Flor. Ind. vol. iii. p. 800), which Roxburgh had identified with one of the forms of Combilium, to the exclusion of Rheede's Kattu-kelengu, the latter being regarded by him a wholly doubtful plant. Fortunately in Roxburgh's plant we at last find something definite and tangible.

There are in Bengal two nearly allied Yams which are involved in our enquiry. One is a common crop, so long under cultivation and so long propagated vegetatively that it has lost the habit of flowering. This Yam is known to the inhabitants as the Susni or Sutni-rlu. The other, which is not always cultivated, is nevertheless a common and favourite article of food. This Yam, which is tolerably plentiful, is known as the Mou-alu, or Moa, a name derived from the Sanskrit term Madh (=sweet). The Mou and the Susni yams are conspecific and the most striking difference between the two is perhaps the fact that whereas the branching roots of the wild plant harden into formidable spines, those of the cultivated one are practically without spines. Early in Roxburgh's botanical career in India he caused figures of each of these plants to be prepared for transmission to the Hon. East India Company, adding the name $D$. aculeata to the figure of the Susni Yam and the name D. spinosa* to that of the Mou Yam. These two figures still exist in duplicate, one copy of each being preserved in the Herbarium at Calcutta, the other of each in the Herbarium at Kew. Subsequent study induced Roxburgh to regard the form with roots which develop into spines as the plant named Combilium by Rumphius and therefore as $D$. aculeata, Linn. (1754, not 1753). The form which had been frgured as $D$. acuileata, being now unprovided with a name, was distinguished by Roxburgh as D. fasciculata, and both the Mou and the Susni, with these revised names, were duly recorded in 1814 (Hort. Beng. p. 74). When at last in 1832 Carey published the descriptions provided a generation earlier by Roxburgh, the accounts of these two Yams appeared under the names duly issued, nearly twenty years earlier, in the Garden Catalogue

* When he proposed this name Roxburgh must have been unaware of the fact that Burmann had used it in 1768 (Hort. Malab. index, p. 5) for Rheede's Katu-Nuren-Kelengu. 
(Flor. Ind. ed. Carey. vol. iii. p. 800 [aculeata] ${ }^{*}$; p. 801 [fasciculata $]$ ). The citations under the diagnosis of $D$. spinosa are "Cumbilium. Rumph. Amb. v. p. 357. t. 126. One of his varieties thereof is no doubt this very plant; but Katta Kelengu, Rheed. Mal. vii. t. 37. is too imperfect a figure to be quoted.' This sentence gives the clue to Roxburgh's change of name. When he originally considered the question he only knew the cultivated Susni Yam. This he identified with the figure of Combilium supplied by Rumphius. Later, somewhere about 1804 (Hort. Beng.), he came to know the Mou Yam. At first he left Susni as D. aculeata and used the ñame D. spinosa for Mou. On reconsideration, this view became modified. He preferred to identify as $D$. aculeata one of the varieties of Combilium described by Rumph rather than that which is the subject of Rumph's plate.

In certain regions, however, the Mou as well as the Susni is the subject of cultivation. Lamarck's reference to its presence in Réunion, with the not very appropriate name of 'Mozambique Yam,' points to it as cultivated there in 1789. Specimens obtained by Rottler and Koenig in Malabar and Coromandel indicate the same thing in Southern India. We know from Thwaites that it is a cultivated plant in Ceylon. Specimens in the Petrograd herbarium prove its introduction and cultivation in the Loo-choo Archipelago. The same thing is true of Northern India.

Hamilton (then Buchanan), the friend and contemporary of Roxburgh, when engaged in his great economic survey of Bengal between 1807 and 1813, gave close attention to this species and came to conclusions that differ a little from those of Roxburgh. His specimens show that he regarded the Susni Yam, from its likeness to the figure which Linnaeus cited from Rumph under the name D. aculeata, Linn. (1754, not 1753) as that to which the Linnean name ought perhaps to be restricted; he inclined in fact to what we know', from his manuscript illustration, was Roxburgh's original view. The cultivated form of the Mou Yam, however, is that which Hamilton preferred to identify with the Combilium to which the main description of Rumph refers; his name for this is accordingly $D$. Combilium, Ham. The uncultivated $M o u$, which Roxburgh originally had figured as $D$. spinosa, Hamilton named $D$. echinata, a sufficient indication that the name spinosa had not been used by Roxburgh in the particular copy of the manuscript Flora Indica which we know to have been in Hamilton's possession.

There are indications that information had reached India of a desire on the part of certain European botanists to learn precisely what the $D$. aculeata or Mou-aloo of the Caleutta garden Catalogue issued in 1814 might be, and to satisfy this desire specimens were secured from one of Roxburgh's actual plants. The label which accompanies one such specimen in the Natural

* Kunth, we have seen, cites this as $D$. aculeata, Roxb., and a reference to the passage shows that the quotation is accurate. But the context suggests that Roxburgh regarded the name as one already in use and a reference to the Hortus Bengalensis shows that Roxburgh did not accept responsibility for the name. 
History Museum, London, bears the legend, in Wallich's handwriting :- "962 Dióscorea aculeata exclusis forsan synon. Rheed. \& Rumph. H. B. C. August 1815." A duplicate of this specimen, now without the original label, is preserved in the Imperial Herbarium, Petrograd. When in 1832 Wallich was engaged in London in the distribution of the Hon. East India Company's herbarium, he appears to have overlooked what Roxburgh had done with regard to the Mou and the Susni Yams in his Hortus Bengalensis and his Flora Indica, ${ }^{*}$ and to have forgot his own action of seventeen years before. Amalgamating in his distribution the Mou and the Susni, as well as other Dioscoreae, Wallich employed for his aggregate the name $D$. spinosa, Roxb., used for the Mou-alu only and even as regards that particular plant altogether discarded when, quite early in his career, Roxburgh decided that the Mou was a form of Combilium and was therefore the plant which in 1754 Linnaeus had named $D$. aculeata. The particular form to which Roxburgh did apply the Linnean name agrees so precisely with Rheede's figure of $M u$-kelengu that the only surprise which those who, profiting by the acumen and sagacity of Hooker in identifying Rheede's plant with the Combilium of Rumphius, now experience, is that botanists so judicious as Roxburgh and Hamilton should have failed to observe that the $M u$ of Malabar and the $M o u$ of Bengal are the same plant, the linked terms Kilengu and $A l u$ being exact equivalents.

The name D. spinosa, Roxb. ex Wall. (Cat. Lith. n.5103), † was

* Copies of Carey's edition of Roxburgh's Flora Indica had not reached London when this distribution took place. But it should be recollected that the Flora Indica of Roxburgh occupies, among works of its kind, the singular position of having been published and in habitual use by botanists many years before it was printed. We have the testimony of Buchanan (afterwards Hamilton) to this effect in a letter dated 11th April, 1797 (Ann. Roy. Bot. Gard. Calrutta, vol. x. pars 2, p. x). Moreover the title-sheet to the second part of Roxburgh's Hortus Bengalensis, dated 1813, indicates that this part consists of a list of those species described by Roxburgh in his Flora Indica which bad not then been introduced to the Hon. Company's Garden at Calcutta. Wallich was one of those who owned a manuscript copy of the Flora Indica; whether he had it with him in London is not known; other copies were already in England in 1832. The case is one with which the wisdom of systematic students in congress assembled has failed to cope equitably; a knowledge of the facts does, however, induce sympathy with Griffith in the strictures which serve as a preface to his edition of the Cryptogamic portion of Roxburgh's Flora, published in 1844 .

+ The results which attend the necessity of working under pressure are unusually manifest in Wallich's treatment of D. spinosa, Roxb. ex Wall. (Cat. Lith. n. 5103). The admixture of species under this number is a trifling drawback as compared with the reduction to a mere jumble of synonyms of the orderly and reasoned treatment elaborated by Hamilton. No injustice is done to Roxburgh in this instance because none of the specimens dealt with had been examined by Roxburgh. It seems in this instance worth while to effect the reductions which Wallich's treatment has rendered necessary.

5103. Dioscorea spinosa, Roxb. A. D. Combilium, H. Ham. Gungachara et Gungachara (Lith. Cat.). Corrected by Wallich himself in Herb. Propr. to "Gungachara et Phuranbari." There is no Gungachara specimen. The one present is written up by Hamilton as follows:-D. Combilium. Phuranbari, $9 \mathrm{Feb}$. 1809 . It is the Mou-alu, forma culta.

P. D. D. hirsuta, H. Ham. e Gualpara et Monghir. There is no Mongyr 
taken up by Hooker who, while rejecting one of the species which Wallich had confused with Mu-kelengu and Combilium, inadvertently accepted another in which the foliage singularly resembles that of $\mathbb{M} u$-kelengu. This species is nevertheless very distinct and approaches more closely in its essential characters to a Central American species, L. cymulosa, Hemsl. (Biol. Cent. Amer. Bot. vol. iii. p. 355. t. 90). So great is the resemblance in this case that Hooker has ventured to reduce the American species to his $D$. spinosa. It should be noted that the description of the female raceme and the fruit of $D$. spinosa (Flor. Brit. Ind. vol. vi. p. 291) is taken, not from the plant described by Roxburgh, but from the species outwardly resembling Roxburgh's plant confused therewith by Wallich.* This species has been described by the writers in 1904 as D. birmanica (Journ. As. Soc. Beng. vol. Ixxiii. pars 2. p. 185).

The Mou-alu, both as a wild and as a cultivated species, is widely spread in India. In Indo-China it is found as a cultivated plant, as it also is in the Mascarenes, Ceylon, the Malayan islands and the southern islands of the Japanese system. In dry Central Burma it is preferred as a crop to the Susni-alu owing to the protection against pigs which the spiny roots afford. The Susni-alu, in many states, is widely cultivated in India and in

specimen. The one present is written up by Hamilton as :-D. hirsuta. Goyalpara, 17 Oct. 1808. It is the Kukur-alu (D. anguina, Roxb.).

C. Moalmyne, 1827. Two specimens both collected by Wallich : one, in fruit, has the field-note "Moalmyn, $8 \mathrm{March}, 1827$ "; the other, a flowering male, has the note "Moalmyn, 11 April, 1827." Both are D. birmanica, Prain and Burkill.

P. D. aculeata, H. Ham. e Monghir. Left without correction by Wallich. The specimen is written up by Hamilton as:-D. aculeata? Nathpur, 21 Sep., 1810. The plant is the Susni-alu (D. fasciculata, Roxb.); Nathpur is in Purnea, not in Mongyr.

P E. D. echinat $t$, H. Ham. e Monghir et Gualpara (Lith. Cat.). Corrected by Wallich himself in Herb. Propr. to "e Bahadurgung et Borybari." There is no Bahadurganj specimen. The one present is written up by Hamilton as follows:-D. echinata. Borybari, 14 Feb., 1809. It is Mou-alu, forma inculta (D. aculeata, Roxb., i.e. D. spinosa, Roxb. ex Wall.). The locality is in Rangpur, bence the necessity for Wallich's correction noted above.

F. Prome, 1827. One specimen collected by Wallich with field-note "montes prope Prome, 15 Sep., 1826." 'I'he plant is D. birmanica, Prain and Burkill.

? G. Napalia inferior, 1820. Two specimens, both collected by Wallich in Dec. 1820 and both marked by him 'Cissampelos.' Both are the Kukuralu (D. anguina, Roxb.).

H. Sillet, F. D. One specimen from Sylhet, collected by F. da Silva, which is the Kukur-alu (D. anguina, Roxb.).

* Some minor inadvertencies have incurred in the writing up and the citation of the Wallichian specimens of Cat. 5103 in the Flora of British India. Thus 5103A (D. combilium, H. Ham.) though cited as 'D. Cernbulium' has been written up as D. anguina; while 5103B (D. hirsuta, H. Ham.) though written up as D. anguina, which it really is, has been cited as $D$. spinosa. 'The remaining citations under $D$. spinosa and $D$. anguina respectively are in conformity with the specimens, subject to the reservation that 5103C and 5103F, being sheets with specimens which Hooker has accepted on Wallich's authority as $D$. spinosa, but which really belong to the very different $D$. birmanica, are to be excluded from $D$. spinosa and $D$. anguina alike. 
Western Malaya. In Malaya east of the Wallace-line and in the Philippines the variety described by Kunth in 1850 as $D$. tiliaefolia is abundant as a wild plant; though conspecific with the Mou-alu or Mu-kelengu it does not come within the discussion for which the Indian plants call in connection with the incidence of the name $D$. sativa.

The earliest name for the species as a whole is $D$. aculeata, Linn., using that name as it was used by Linnaeus in 1754 (Amoen. Acad. vol. iv. p. 131), and this is the name that has come into general use. The verdict of Hooker, that this name cannot be used because this is not the plant to which Linnaeus applied the name $D$. aculeata in 1753 ( $S p$. Pl. ed. 1. p. 1033) is, however, unimpeachable. So long as the position of D. aculeata, Linn. (1753), the authority for which is the Kattu-Kelengu of Rheede (Hort. Malab. vol. vii. p. 71. t. 37), remained doubtful, the continued misuse of the Linnean name was free from inconvenience. Now, however, that it is clear that the species named $D$. aculeata by Linnaeus in 1753 is a member of the section Enantiophyllum and is the one described by Hooker in 1892 as D. Wallichii, Hook. f. (Flor. Brit. Ind. vol. vi. p. 295), it is no longer possible to employ the name $D$. aculeata for the $M u$ of Rheede and the Combilium of Rumphius. The oldest name within the genus is that of $D$. fasciculata, Roxb., a usage adopted by one of us in 1903 (Beng. Pl. vol. ii. p. 1066). There is however now no room for doubt that the plant described by Loureiro as Oncus esculentus (Elor. Cochinchin. vol. i. p. 194) in 1793 is the Mu Yam. This being so, the dictates governing nomenclature that are now in force demand the use of the new combination $D$. esculenta.*

When we come to consider the last of the six elements included by Linnaeus under $D$. sativa we find ourselves confronted by a more serious difficulty than any with which we have yet had to deal. This element, $D$. sativa, Linn. [1], is the plant figured by Ehret in 1737 (Hort. Cliff. t. 28) which, as Hooker and Bentham and Lamarck and Grisebach have all pointed out, must be accepted as the basis of $D$. sativa, Linn. Views as to the identity of this plant have been somewhat varied. The extremes have been that of Lamarck who would not venture to suggest what it is unless it were perchance the plant in cultivation in Paris in 1789 as $D$. sativa, which Lamarck could not distinguish from the species depicted in a figure published by Plukenet that Linnaeus had cited under his $D$. villosa; and that of Bentham who has expressed himself as satisfied that Ehret's plate is an acceptable representation of one of the two species included by Linnaeus under his $D$. bulbifera, to which species, as a consequence of this judgment, the name $D$. sativa, Linn., has by many recent authors been transferred.

When regard is had to the circumstance that Ehret was the artist concerned, we are justified in assuming that the picture represents with some approach to fidelity the object or objects depicted. This being the case it may be said at once that, owing to the disposition of the secondary venation, the leaves in Ehret's

* One of us has communicated this suggestion to Dr. E. D. Merrill, who has formally adopted the name as D. esculenta, Burkill (Interp. Rumph. Herb. Amboyn. p. 147). 
plant are those of some species altogether different from D. sativa, Benth. and, owing to the outline of the capsules, the fruit in Ehret's plant is that of a species quite remote from 7 . sativa, Benth. But while it is thus certain that $D$. sativa, Benth. cannot be the species which Linnaeus accepted as the basis of D). sativa, Linn., we are not brought nearer to the identity of the Ehret plant.

The suggestion made by Lamarck in 1789 was in essence accepted by Kunth in 1850 and there is no doubt, when examples of $D$. villosa, Linn., are compared with Ehret's plate that, as regards the leaves, that plate may be accepted not only as a good but as a singularly accurate representation of this North American species. The difficulty which the plate then presents resides in the fact that the fruiting spike shows the capsules of a species which we know from experience should contain seeds which are winged at the ton only, and that they are in shape, size and appearance wholly unlike the capsules of $D$. villosd, Linn., in which the seeds are winged all round. The two facts mentioned can only be reconciled if we assume that the leaves and the fruit depicted by Ehret were taken from different specimens belonging to different species. That the leaves and the the fruit were in fact derived from different specimens we already know. The plant described by Linnaeus (Hort. Cliff. p. 459) had not flowered in 1737 ; the fruits shown therefore either came from that plant in a later year or belonged to some other plant. An examination of the figure shows that the rachis of the fruiting spike is made to leave the stem nearly but not quite from the axil of the subtending leaf, and that this rachis is made to diverge from the stem at an unnatural angle. It is also noticeable that at the time the fruiting spike was added to the plate a stipulary prickle was added at the base of the subtending petiole but placed at the upper aspect of the petiole instead of at the point where a stipulary prickle would normally be situated. The conclusion, indeed, to which an examination of the plate leads is that both the fruiting spike and the stipulary thorn were added after the main figure was drawn and the style in which these additions to Ehret's figure have been executed induces some suspicion that they may have been the work of another artist. The circumstance to which we have already adverted, that Linnaeus did not refer to the figure of $D$. foliis cordatis alternis, caule laevi in his text and that both Royen in 1740 (Flor. Leyd. Prodr. p. 527) and Linnaeus himself in 1747 (Flor. Zeyl. p. 170) have avoided the citation of this plate, at least suggests the possibility that there was some doubt in their minds as to the congruity of the foliage and the fruit.

Fortunately the matter no longer remains doubtful. The specimen from which the drawing of the fruiting spike shown in the Hortus Cliffortianus figure was made is still available for study in the Natural History Museum collection at South Kensington. It is in fact the Cliffortian specimen which purports to represent the species now under discussion and though it bears no legend in the handwriting of Linnaeus, it had been written up as $D$. sativa, by some early student, before it became the property of the British Museum. The leaves and stem of 
this specimen are singularly unlike the leaves and the stem of Ehret's figure and therefore equally unlike those of any specimen of any of the forms of $D$. villosa, Linn. The leaves and stem are, however, exactly those of $\nu$. chondrocarpa, Griseb. (Flor. Bras. vol. iii. p. 34) and the specimen might without hesitation be identified as $D$. chondrocarpa but for the circumstance that none of the leaves present exhibit the stipulary prickles so characteristic of that species, This objection is not wholly insuperable. The specimen, obviously derived from a plant grown under stove conditions, is taken from high up on a branch, and even in wild specimens these prickles towards the ends of the branches tend to become small and at times are absent. Moreover, as we have seen, the artist who added the fruiting spike to Ehret's plate has been at pains to add also a stipulary prickle. This he was not likely to have done had not the presence of such prickles on some part of the plant whence this specimen was derived arrested his attention.

The description of $D$. chondrocarpa provided by Grisebach in 1842 is not the earliest account of this species at our disposal. It is the plant figured by Burmann in 1755 (Pl. Amer. Plum. vol. i. p. 73. t. 83) as China Michuacanensis, sive S'milax aspera minor, Boyaux du Diable-in Plumier's MSS. named China Michuanensis, seu phaeo Kechi* ; and referred by Burmann (l.c.) to Smilax caule aculeato, foliis inermibus ovatis retuso-mucronatis, i.e. to Smilax Sarsaparilla, Linn. (Sp. Pl. ed. 1. p. 1029). Being a Dioscorea and not a Smilax it is not $S$. Sarsaparilla, Linn., though we now know from Burchell that it is the plant whose rhizomes vield the genuine 'Salsaparillia' of commerce. Willdenow in 1806 rectified the error into which Burmann had fallen as to the specific identity of this plant, but unfortunately without observing that it is not a Smilax but a Dioscorea; it appears in his work as Smilax acuminata (Sp. Pl. ed. Willd. vol. iv. p. 779). The fact that this plant is the source of the true Sarsaparilla affords a possible explanation of its presence in the collection of so ardent a grower of rare and interesting species as the owner of the famous garden at Hartekamp.

A native of Brazil, the reputation of the drug it yields, and the

* As the description supplied by Burmann is very condensed, and as he has inadvertently referred the plant not only to a species but to a geuus to which it does not belong, we take this opportunity to print Plumier's original description in full :-

China michuacanensis seu phaeo Rechi Lib. v. cap. Iv.

Huius etiam nec flores nec fructus potui observare curiose licet conquisitos. Ejus radix dura est et compacta radicum arundinacearum instar intus rubens adstringens et amariuscula deforis vero e russo nigricans tuberculis nodosa ac innumeris fibris longis et duris stipata, ex ea sarmenta quaedam proveniunt dimidium digitum fere crassa solida seu dura virentia aculeis ruborum nostratum instar armato altissime tandem super vicinas arbores corscendentia ac ramos quosdarn emittentia foliaque quaedam cordata, acumine longo donata, quatuor poltices circiter ampla glabra superius sature inferius vero diluto virentia costulisque septem plantagininis [plantaginis] in morem sustentata.

Pluribus in locis reperitur haec planta apud insulam martinicensem ubi vulgus eam boyanx du Diable appellant eo qnod intestineorum [sic] funicolum instar sarmenta ojus frangi contumacissima existant.

Similacis forte est species. 
unfortunate necessity for its employment, sufficiently accounts for the introduction of this species to Guiana and to the Antilles, where it extends from Trinidad, St. Vincent and Martinique to Porto Rico.

In spite of the identity of Smilax acuminata, Willd., and $D$. chondrocarpa, Griseb., the latter name was still the one recognised by Uline in $189 \pi$ (Engl. Nat. Pflanzenfan. Nachtr. II.-IV. p. 84) and although we are aware that the name first used in 1842 cannot be sustained, we do not propose here to suggest the new combination which the identity of these two plants seems to call for, owing to the circumstance that it is not impossible that in the 'Boyaux du Diable' we may have only to deal once again with the Polygonatum of Plumier which was in 1789 made by Lamarck the basis of his D. altissima. An examination of the two plates published by Burman (Pl. Amer. Plum. t. 83 and t. 17\%. fig. 2) shows that Smilax acuminata and D. altissima have the same foliage; a comparison of the two descriptions by Plumier shows that they have the same underground stem and the same habit. One very serious difficulty is that in D. altissima as figured by Plumier the leaves are opposite. The numerous specimens studied by us show that in Smilax acuminata (D) chondrocarpa) the leaves occasionally are opposite or nearly so, but they are never so strictly and habitually opposite even on the lower stem as in the case of $D$. alata or $D$. cayenensis, both of.these, but especially the latter, being provided with branches, on some of which all the leaves are opposite while on others all are alternate. There is another, and perhaps more serious difficulty; the male flowers of $I$ ). chondrocarpa have a glabrous perianth, whereas the female flowers of $D$. altissima are described by Plumier as having a pubescent perianth, and until D. altissima, Lamk, which has never been met with since Plumier made his drawing and description, can be studied from actual specimens from Martinique, it seems for the moment desirable to leave it an open question as to the identity of $D$. chondrocarpa and $D$. altissima. This uncertainty, however, does not affect the question immediately before us, which is the identity of $D$. sativa, Linn. [1].

Had the Linnean citation of the Hortus C'liffortianus in 1753 beenidentical with the Linnean citation of 1747 (Flor.Zeyl.p.170) and with that of Royen in 1740 (Flor. Leyd. Prodr. p. 527); had it been confined to the page (Hort. Cliff. p. 459) and therefore to the plant there somewhat inadequately described; we might have been justified in deciding that $D$. sativa, Linn. [1], and $D$. villosa, linn. (Sp. Pl. ed. 1. p. 1033), are conspecific. The question for settlement then would have been which of the two names, simultaneously published by him for the same species, it is desirable to retain; which of the two it is necessary to discard. But in 1753 Linnaeus, with less caution than he had hitherto displayed, cited not only the page with his own text but the plate with Ehret's figure, under D. sativa, Linn. (Sp. Pl. ed. 1. p. 1033); the figure in question becomes, as a consequence, at least some part of the authority for his species; as the figure is a composite one, the "species" is, even at its inception, not a natural species, and the name $D$. sativa is without a definite basis. The judgment of 
Lamarck in 1789 had a firmer foundation even than that author imagined, and the name $D$. C'liffortiana, Lamk, also disappears.

Our endeavour to answer the question "What is D. sativa, Linn.?" has led us into unexpected bye-paths and has produced some unexpected results. A brief summary of these results may not be without interest.

Two authors who have used the name-Sieber in 1821 and Bowdich in 1825-have applied the name to individual species which do not belong to the genus Dioscorea.

Fight authors-Thunberg in 1784, Rodschied in 1796, Presl in 1827, Bunge in 1831, Wallich in 1832, Grisebach in 1842, Bentham in 1861, Miquel in 1865-have applied the name $D$. sativa to species other than any of those included under the name by Linnaeus. At least two of these-Grisebach and Benthamwere aware that the Linnean $D$. sativa, so far as citation is concerned, covers several different species.

Other authors, however, have been alive to this fact. Gaertner in 1788 implied the exclusion of a West Indian plant cited by Linnaeus from Sloane; Willdenow in 1806 expressly excluded another West Indian plant cited by Linnaeus from Plumier; Meyer in 1818 excluded an Amboyna plant cited by Linnaeus from Rumph; Presl in 1827 excluded both the West Indian plant from Plumier and the Amboyna plant from Rumph. Maycock in 1830 by citation excluded everything save the unarmed condition of the West Indian cultivated Yam taken up by Linnaeus from Sloane; Dillwyn, in 1839, in practice excluded everything except one of Rheede's Malabar Dioscoreas. Kunth in 1850 excluded, in intention, everything save a Ceylon plant taken up by Linnaeus from Hermann and a Malabar plant taken up from Rheede. Thwaites in 1864 excluded everything save Rheede's Malabar plant, and was followed in this by Hasskarl in 1867.

Four authors-Lamarck in 1789, Grisebach in 1842, Bentham in 1861, Hooker in 1892-have expressed the conviction that the subject of Ehret's plate (Hort. Cliff. t. 28) must be regarded as the authority of Linnaeus for the species $D$. sativa, Linn. ( $S p . P l$. ed. 1. p. 1033). It is significant that three of these authorsGrisebach, Bentham, Hooker-have used the name for species of Dioscorea which Linnaeus never did include in $D$. sativa, and that Lamarck, who did confine himself strictly to the subject of Ehret's plate, admitted his inability to identify the species there depicted.

Lamarck in 1789 thought it desirable to suppress the name D. sativa and to use instead the name D. Cliffortiana. In this Lamarck has been followed only by Poiret in 1823 and by Kunth in 1850. It is again significant that Poiret applied the name D. Cliffortiana in connection with a plate (Lamk. Ill. t. 818) on which are shown two species which Lamarck had excluded from D. Cliffortiana and that Kunth still confessed his inability to recognise Ehret's plant.

Turning now to the components of $D$. sativa, Iinn., as indicated by the citations of Linaeus we find that two of these are not members of the genus Dioscorea; the others do belong to the genus. 
'The Amboyna plant cited from Rumph is Cardiopteris Rumphii, Baill. (Adansonia, vol. x. p. 280), by some authors regarded as no more than a form of Cardiopteris lobata, $\mathbf{R} . \mathrm{Br}$. (Wall. ('at. lith. 8033A);

The Ceylon plant cited from Hermann is Tinospora cordifolia, Miers;

The West India plant cited from Plumier is Discorea martinicensis, Spreng.;

The West Indian plant cited from Sloane is $D$. cayenensis, Lamk ;

The Malabar plant cited from Rheede is $D$. esculeata, Burkill (Oncus esculentus, Lour.); finally,

The figure by Ehret (Hort. Cliff. t. 28) regarded by Lamarck, Grisebach, Bentham, and Hooker as the authority for D. sativa, I.inn., is certainly composed of a combination of two different species. One of these, which is referred to in the accompanying text (Hort. Cliff. p. 459), is D. villosa, Linn.; the other, to which the text makes no allusion, is $D$. chondrocarpa, Griseb. (Smilax acuminata, Willd.).

There is no room for doubt that when he used the name $D$. sativa it was the intention of Linnaeus to so designate one of the species of Dioscorea cultivated as an article of food. If this intention be taken into account it is manifest that we must exclude from cousideration all the elements of his aggregate except $D$. sativa [3], which is the Mu-kelengu of Rheede from the Fast Indies, and D. sativa [4] which is the Volubilis nigra, folio cordato nervoso of Sloane. As these two are distinct species, belonging respectively to the very different sections Combilium and Enantiophyllum, the name cannot be applied to both. In 1737, 1747 and 1753 Linnaeus cited the East Indian edible and cultivated plant, the 'Lesser Yam' of India, before citing the 'Negro Yam' of the West Indies. Blume, Dillwyn, Kunth and Thwaites were therefore, from this particular standpoint, justified in recommending the restriction of the name $D$. sativa to the Lesser Yam, the more especially since Linnaeus had refrained both in 1737 and in 1747 from citing the figure by Ehret as a figure of his species. But by his citation, in 1753, when he first proposed the epithet 'sativa,' of the figure in question as the basis of his species, Linnaeus defeated in advance the intention these authors had in view. As Hooker has stated (Flor. Brit. Ind. vol. vi. p. 291) " the plant figured in "Hortus Cliffortianus' must be accepted as sativa, Linn." Since the plant so figured is a chimaera, the original portion of which represents the stem and leaves of a species (D. villosa) which Linnaeus himself named and characterised in 1753, that is not a cultivated edible Dioscorea, while the added fruiting spike and prickle belong to another species with medicinal properties, the name $D$. sativa becomes one that cannot be used. 